\title{
Czy KPP była patriotyczna? Dyskusja w Wydziale Historii Partii wokół referatu Tadeusza Daniszewskiego na temat „sprawy niepodległości w ruchu robotniczym"
}

\begin{abstract}
Abstrakt: Przedmiotem artykułu jest analiza referatu Tadeusza Daniszewskiego „Sprawa niepodległości w ruchu robotniczym" oraz dyskusji, którą wywołał na forum Wydziału Historii Partii jesienią 1946 r. Tekst ukazuje znaczenie ideologii w początkach władzy komunistycznej w Polsce po zakończeniu II wojny światowej oraz ciagłość dawnych sporów wewnątrz szeroko pojętego ruchu robotniczego, dotyczących stosunku do niepodległości. Dotyka problemu ewolucji ideowej przedwojennych komunistów w obliczu konieczności legitymizacji systemu.
\end{abstract}

Słowa kluczow e: Komunistyczna Partia Polski, Polska Partia Robotnicza, ruch robotniczy, niepodległość, legitymizacja, historiografia.

Abstract: The article presents an analysis of Tadeusz Daniszewski's report entitled "The question of independence in the workers' movement" and the discussion at the Department of the History of the Party that followed it in the autumn of 1946. The text pays attention to the importance of ideology in the early period of communist rule in Poland after the end of World War Two, and the continuity of old controversies within the broad workers' movement concerning the attitude towards independence. It also brings up the problem of ideological evolution of pre-war communists faced with the need to legitimise the new political system.

Keyw ords: Communist Party of Poland, Polish Workers' Party, workers' movement, independence, legitimisation, historiography.

Stosunek do niepodległości Polski, a wręcz zasadności istnienia jej jako suwerennego bytu państwowego, wywoływał różnicę zdań wśród działaczy szeroko rozumianego ruchu robotniczego od jego zarania. Podziały na tym 
tle nie traciły na aktualności również po zakończeniu II wojny światowej i zdominowaniu sceny politycznej przez PPR. Interesujacym świadectwem tego sporu jest referat Tadeusza Daniszewskiego „Sprawa niepodległości w ruchu robotniczym”, wygłoszony przezeń na forum Wydziału Historii Partii jesienia 1946 r. $^{1}$

Analiza wystapienia Daniszewskiego i dyskusji wśród zgromadzonych w niniejszym artykule stanowi punkt wyjścia szerszych rozważań na temat stosunku komunistów o przedwojennym rodowodzie do sytuacji politycznej i społecznej Polski po 1945 r. Wybór źródła nie jest przypadkowy. Z jednej strony dokument ten stanowi unikatowy zapis emocji towarzyszących debacie, z drugiej - rzuca światło na konflikt wewnątrzpartyjny 1948 r. Protokół dyskusji członków WHP, nawet przy uwzględnieniu możliwych ingerencji w jego treść, ujawnia atmosferę panująca w środowisku, które miało kształtować świadomość historyczna Polaków przez najbliższe lata. Środowisku, które - warto podkreślić - było bezsprzecznie zdominowane przez przedwojennych komunistów. Referat Daniszewskiego pozwala również uzmysłowić sobie, jak ważną rolę, wbrew stereotypowym wyobrażeniom, odgrywała ideologia w początkach władzy komunistycznej w Polsce, nie tylko w aspekcie propagandowym.

Ewolucja ideowa działaczy Komunistycznej Partii Polski po jej rozwiazaniu, jak i dzieje samej partii nie cieszyły się dużym zainteresowaniem historyków po 1989 r. Mimo ułatwionego dostępu do źródeł archiwalnych nie powstała dotąd żadna naukowa monografia jej poświęcona ${ }^{2}$. W ostatnich latach ukazywały się przede wszystkim studia dotyczące działalności struktur terenowych KPP oraz publikacje o charakterze biograficznym. Sa to jednak w większości opracowania stricte faktograficzne, zawierające głównie statystyki oraz dane liczbowe. Prawdopodobnie stanowi to w dużym stopniu reakcję na zbyt duże nasycenie prac z okresu PRL, zwłaszcza tych związanych z tematyką KPP, aktualnymi wówczas aspektami ideologicznymi. Podobnie przedstawia się sprawa PPR. W istniejącej literaturze przedmiotu

\footnotetext{
${ }^{1}$ Referat w: Archiwum Akt Nowych (dalej: AAN), Komitet Centralny Polskiej Partii Robotniczej (dalej: KC PPR), sygn. 295/XIX-12. Protokół dyskusji oraz kopia referatu nieznacznie różniąca się od pierwowzoru znajdują się w aktach o sygnaturze: AAN, KC PPR, sygn. 295/XIX-5.

${ }^{2}$ Wyłamuje się do pewnego stopnia z tego uogólnienia książka Krystyny Trembickiej. Zob. eadem, Między apologia a negacja. Studium myśli politycznej Komunistycznej Partii Polski $w$ latach 1918-1932, Lublin 1995. W ostatnich latach ukazały się również prace zbiorowe na temat polskich komunistów. Zob. m.in.: M. Korkuć, W II Rzeczypospolitej, w: Komunizm $w$ Polsce. Zdrada, zbrodnie, zaktamanie, zniewolenie, Kraków 2005; Polska Partia Robotnicza, Gwardia Ludowa/Armia Ludowa na ziemiach polskich 1942-1944/1945, red. K. Kaczmarski, M. Krzysztofiński, Rzeszów 2013; Polska Partia Robotnicza 1944-1948. Studia i szkice, red. M. Krzysztofiński, Rzeszów 2014; Komuniści w międzywojennej Warszawie, red. E. Kowalczyk, Warszawa 2014; Komuniści w II Rzeczypospolitej. Ludzie - struktury działalność, red. M. Bukała, M. Krzysztofiński, Rzeszów 2015.
} 
próżno szukać głębszego studium tożsamości ideowej tego środowiska oraz śladów wpływu przedwojennej mentalności partyjnej na oblicze środowiska komunistycznego po wojnie ${ }^{3}$.

Analiza dyskusji na temat referatu stanowi również znakomity punkt wyjścia rozważań na temat szerszej, fascynującej kwestii, a mianowicie pamięci byłych kapepowców o KPP i dziedzictwie przedwojennego ruchu komunistycznego. Zagadnienie to wiąże się nie tyle z ustalaniem faktów z historii partii, realnego przebiegu wydarzeń i ich przyczyn, ile z badaniem sposobu ich postrzegania, zapamiętywania, interpretowania i utrwalania przeszłości. Trzeba mieć przy tym świadomość, że uchwycenie nastrojów, zbiorowych emocji i oddziaływania rozmaitych mechanizmów psychologicznych przysparza wielu trudności metodologicznych.

Za najważniejszą należałoby uznać niebezpieczeństwo bezkrytycznego przyjęcia punktu widzenia analizowanych postaci. Nie ulega wątpliwości, że argumentacja Daniszewskiego i dyskutantów stanowi swoistą interpretację dziejów, rojącą się od sprzeczności, pełną półprawd i przekłamań. Moim celem nie jest systematyczne ich prostowanie ani ocena słuszności wywodu, a jedynie próba ułatwienia zrozumienia zawiłego przekazu, wyrażonego bardzo hermetycznym dla współczesnego czytelnika językiem. Warto pamiętać, że zrozumienie wywodu siłą rzeczy wymaga odwołania się do faktografii. W tej kwestii historyk napotyka kolejne utrudnienie. Jak już wspomniałam, wciąż brakuje rzetelnych publikacji dotyczących samej KPP, co pociaga za sobą konieczność sięgania do prac sprzed 1989 r. Historiografia ta jest niezwykle obfita, jednak zmienność kursu politycznego, przetasowania na scenie partyjnej oraz ingerencje cenzury znacząco rzutowały na dokonywane „korekty” interpretacyjne ${ }^{4}$. Z tych powodów brakuje niepodważalnej podstawy

\footnotetext{
${ }^{3}$ Pewien wyjątek stanowi tu biografia Romana Zambrowskiego. Zob. M. Szumiło, Roman Zambrowski 1909-1977. Studium z dziejów elity komunistycznej w Polsce, Warszawa 2014. Poprzez biografię „pretekstowa” celem autora jest scharakteryzowanie środowiska politycznego Zambrowskiego. Zob. też: M. Szumiło, Elita Polskiej Partii Robotniczej (1944-1948). Portret historyczno-socjologiczny, w: Polska Partia Robotnicza 1944-1948..., s. 162-189; P. Siergiejczyk, Kulturowy fenomen polskiej sekcji Kominternu, w: Komuniści w II Rzeczypospolitej..., s. 293-308.

${ }^{4}$ Zob. m.in.: M. Meglicka, Prasa Komunistycznej Partii Robotniczej Polski w latach 1918-1923, Warszawa 1968; F. Świetlikowa, Komunistyczna Partia Robotnicza Polski 1918-1923, Warszawa 1968; H. Karwacka, Witold Wandurski, Łódź 1968; L. Krzemień, Spór o dziedzictwo ideowe KPP, Warszawa 1970; F. Kalicka, Julian Brun-Bronowicz. Życie, działalność, twórczość, Warszawa 1973; J. Kowalski, Komunistyczna Partia Polski 1935-1938. Studium historyczne, Warszawa 1975; S.S. Nicieja, Julian Leszczyński-Leński, Warszawa 1979; H. Cimek, L. Kieszczyński, Komunistyczna Partia Polski 1918-1938, Warszawa 1984; B. Kolebacz, Komunistyczna Partia Polski 1923-1929. Problemy ideologiczne, Warszawa 1984; A. Czubiński, Komunistyczna Partia Polski (1918-1938). Zarys historii, Warszawa 1985; Tragedia Komunistycznej Partii Polski, red. nauk. J. Maciszewski, Warszawa 1989; H. Cimek, Komuniści, Polska, Stalin, 1918-1939, Białystok 1990.
} 
faktograficznej, która stanowiłaby punkt odniesienia i pozwoliła weryfikować narrację autora oraz uczestników dyskusji.

Wiele trudności nastręcza ponadto język źródeł. Dziś komunistyczna nowomowa, powszechnie uznawana za swoiste pustosłowie i element ówczesnego języka propagandy, wywołuje negatywne konotacje w sferze świadomości. Mimo to zupełna rezygnacja z przytaczania nie wydaje się możliwa. Należy pamiętać, że nowomowa partyjna zawiera wyrażenia językowe odpowiadające zbitkom pojęciowym nieodłącznym od ideologii marksistowskiej. Zastępowanie owych wyrażeń innymi zwrotami wymagałoby każdorazowo określenia ich pól semantycznych. Starając się zatem zinterpretować znaczenie kluczowych wyrażeń, haseł i pojęć, nie zdecydowałam się na ich całkowite wyeliminowanie. Większość z nich umieściłam w cudzysłowach. Dodatkowo należy podkreślić, iż wobec tak sztywnych ram i pojęciowych schematów obowiązującego wówczas języka wyłonienie treści ,indywidualnych” u poszczególnych dyskutantów było niezwykle trudne, co jednak starałam się w niniejszym artykule uczynić.

Dla właściwego zrozumienia treści referatu Daniszewskiego warto spojrzeć na szerszy kontekst polityczny czasu, w którym go opracowano. W wielu krajach, w których wojska niemieckie zostały wyparte przez armię sowiecka, jesień 1946 r. tworzyły się tzw. fronty narodowe. Był to zatem okres podejmowania tymczasowej współpracy z wszystkimi „demokratami” (w rozumieniu komunistów) w celu przyciagnięcia ku nowej władzy w danym kraju jak największej liczby zwolenników. Aby to ułatwić, już 15 V 1943 r. rozwiązano Międzynarodówkę Komunistyczna, ale oczywiście nie oznaczało to, że Kreml zrezygnował z nadzoru nad partiami komunistycznymi. Funkcję tę pełnił odtąd Wydział Informacji Międzynarodowej KC WKP (b), kierowany przez Georgiego Dymitrowa. Pochodna kremlowskiej strategii było zakamuflowanie przez PPR jej komunistycznego rodowodu. Głosiła zatem hasła „utrwalania” niepodległości Polski oraz odbudowy kraju, o ustroju zachowujacym pozory demokracji parlamentarnej ${ }^{5}$.

Od chwili powołania przez Bolesława Bieruta 28 VI 1945 r. Tymczasowego Rządu Jedności Narodowej, mimo koalicyjnego charakteru gabinetu, w skład którego weszły PPR, PPS, SD i SL, i obecności legalnej opozycji w postaci PSL, PPR zajmowała pozycje „,hegemona”, jak określał to wówczas Władysław Gomułka ${ }^{6}$. Chociaż formalnie nie posiadała przewagi w rządzie, jej ludzie obejmowali kluczowe resorty, w tym Ministerstwo Bezpieczeństwa

\footnotetext{
${ }^{5} \mathrm{Na}$ temat kontrowersji wokół pojęcia „demokracja ludowa”, niejednoznacznie rozumianego przez kierownictwo PPR, zob. J. Jagiełł, O polska drogę do socjalizmu. Dyskusje w PPR i PPS w latach 1944-1948, Warszawa 1983; S. Ciesielski, J. Juchnowski, Dylematy i poszukiwania. Studia nad polska myśla socjalistyczna 1939-1948, Wrocław 1991.

${ }^{6}$ Protokół plenarnego posiedzenia Komitetu Centralnego [PPR] odbytego w Warszawie w dniu 18 września 1946 r., w: S. Ciesielski, Transformacja ustrojowa ustroju politycznego Polski w latach 1944-1948, http://www.sciesielski.republika.pl/varia/transform.html (dostęp: 29 IX 2016).
} 
Publicznego, oraz kontrolowali wojsko i milicję. Dysponowała zatem narzędziami pozwalającymi na ingerencję w kompetencje resortów, które nie były im formalnie podporządkowane, oraz stosowanie bezwzględnych represji politycznych, a nawet terrorystycznych wobec jedynej jawnej opozycji, czyli PSL.

Dyskusję o referacie Daniszewskiego podjęto zaledwie dwa miesiące po tzw. referendum ludowym. Na wspólną listę PPR, PPS, SL, SD głosy oddało nie więcej niż $26,9 \%$ ogółu głosujących. Rezultat ten nie pozostawiał żadnych złudzeń co do realnego poziomu zaufania społecznego, jakim się cieszyły te partie. Zgodnie z planem wybory do Sejmu Ustawodawczego miały się odbyć pół roku później. Rozważanie możliwości sfałszowania kolejnej elekcji nie oznaczało zaniechania starań o legitymizację władzy. Do pewnego stopnia wynikało to $\mathrm{z}$ sytuacji na arenie międzynarodowej. Jakkolwiek Stany Zjednoczone i Wielka Brytania byłyby niechętne interwencji w razie niedotrzymania zobowiązań jałtańskich, zbyt jawne ich pogwałcenie mogłoby doprowadzić do niekorzystnego zaostrzenia stosunków z Zachodem. Ponadto sfałszowanie wyborów nie zmniejszało oporu społeczeństwa, zarówno wówczas, jak i w przyszłości?

W kwestiach związanych z potrzebą wzmocnienia legitymizacji władzy dużą rolę do odegrania miał m.in. WHP przy KC PPR. Istniejące zapotrzebowanie, które związane było także z koniecznością odpowiedniego przygotowania własnych kadr, sprawiło, że przystapiono do masowej publikacji artykułów, opracowań dla dziennikarzy oraz wykładów dla działaczy partyjnych ${ }^{8}$. Wśród zachowanych materiałów archiwalnych pozostałych po WHP nie ma praktycznie żadnych większych opracowań. Zachowały się jedynie spisy tytułów tych publikacji. Wyjątkiem jest referat ówczesnego członka wydziału, Daniszewskiego. Został on wygłoszony 15 IX 1946 r. i był - w opinii jego audytorium - powiązany z przygotowywaniem monografii pt. Zarys historii polskiego ruchu robotniczego, które to opracowanie zostało mu powierzone.

Planowanie owej syntezy na tak wczesnym etapie sprawowania władzy wynikało z istnienia różnic poglądowych wewnątrz partii - co w dużej mierze było spadkiem po przedwojennych walkach frakcyjnych - jak i konieczności odpowiedniego uformowania szeregowych członków partii, których liczba stale

\footnotetext{
${ }^{7} \mathrm{Na}$ temat referendum z 1946 r. i wyborów do Sejmu Ustawodawczego z 1947 r. zob. m.in.: Kampania wyborcza i wybory do Sejmu Ustawodawczego 19 stycznia 1947, wybór i oprac. J. Wrona, Warszawa 1999; Cz. Osękowski, Referendum 30 czerwca 1946 roku w Polsce, Warszawa 2000; idem, Wybory do sejmu z 19 stycznia 1947 roku w Polsce, Poznań 2000; M. Łatyński, Referendum, w: idem, Nie paść na kolana. Szkice o polskiej polityce lat powojennych, Wrocław 2002; M. Skoczylas, Wybory do Sejmu Ustawodawczego z 19 stycznia 1947 r. w świetle skarg ludności, Warszawa 2003; J. Wtorkiewicz, Wojsko Polskie w akcji propagandowej $i$ wyborach do Sejmu Ustawodawczego w 1947 roku, Warszawa 2002. Ponadto zob. A. Mazurkiewicz, Dyplomacja Stanów Zjednoczonych wobec wyborów w Polsce w latach 1947 i 1989, Warszawa 2007.

${ }^{8}$ Zob. m.in.: AAN, KC PPR, sygn. 295/X-76.
} 
wzrastała. O wadze, jaka przywiąywano do tej sprawy, świadczy fakt, że Sekretariat KC PPR powołał komisję mająca nadzorować pracę nad książka oraz na bieżąco ją recenzować. Wcześniej nie zaprezentowano komisji żadnego fragmentu opracowania. Dysponujemy jednak listem Daniszewskiego do członków Komisji przy WHP z 21 X 1946 r., w którym zastrzegał się, że stenogram referatu nie jest częścia pracy Historia ruchu robotniczego $w$ Polsce. W przyszłej syntezie nie zamierzał poświęcić zbyt wiele miejsca „zagadnieniom takich czy innych odchyleń”. Tym bardziej daje do myślenia wybór tematu wystapienia 15 września.

Dyskusja wokół stanowiska poszczególnych partii robotniczych, w tym także PPS, względem niepodległości Polski, przywołuje na myśl wygłoszony zaledwie dwa lata później, na plenum KC 3 VI 1948 r., słynny referat Gomułki. Jego tezy zostały wówczas napiętnowane jako objaw „odchylenia prawicowo-nacjonalistycznego". Wystapienie Gomułki odegrało rolę zapalnika konfliktu politycznego wewnątrz partii, co w konsekwencji spowodowało usunięcie autora ze stanowiska pierwszego sekretarza KC.

Jak wynika z materiałów WHP, ustalenie pewnych wytycznych co do problematyki tradycji niepodległościowych miało kluczowe znaczenie już w roku 1946. Wypowiedź członka WHP, Artura Starewicza, w ramach dyskusji, jaka zawiązała się po odczytaniu referatu Daniszewskiego, podsumowuje najdobitniej dylemat, przed którym stali komuniści ${ }^{10}$. Można go streścić następująco: dawniej mówiliśmy, że dla rozwoju gospodarczego dobrze byłoby, aby Polska stanowiła część ZSRR, dziś jesteśmy przeciwni tzw. 17 republice. Konstatacja Starewicza: „Dziś zajmujemy inna pozycję, a to uzasadnione jest zupełnie zmiana sytuacji, innym układem sił klasy robotniczej"11, wynikała z przekonania, iż w istocie stosunek do kwestii niepodległości Polski był dla władzy największym obciążeniem. Stąd właśnie wyłoniła się kwestia, jak „oczyścić” wizerunek ludzi stojących na czele PPR, na których w okresie międzywojennym wisiało społeczne odium przynależności do KPP, czyli partii, która w istocie negowała istnienie państwa polskiego ${ }^{12}$.

9 AAN, KC PPR, sygn. 295/XIX-12, k. 4.

10 Artur Starewicz (1917-2014), inż. chemik. Członek WKP(b), PPR (od 1945), PZPR (od 1948). W latach trzydziestych młodzieżowy działacz komunistyczny. Podczas II wojny światowej w ZSRS; powrócił do kraju we wrześniu 1944 r. W latach 1944-1954 pełnił funkcje kierownicze w Wydziale Propagandy. Zastępca redaktora naczelnego „Trybuny Ludu” (1956), kierownik Biura Prasy KC PZPR (1956-1963), poseł na Sejm PRL II-V kadencji (1956-1972), ambasador PRL w Wielkiej Brytanii (1971-1978). Więcej zob. T. Mołdawa, Ludzie władzy 1944-1991. Wtadze państwowe i polityczne Polski wedtug stanu na dzień 28 II 1991, Warszawa 1991, s. 425.

11 AAN, KC PPR, sygn. 295/XIX-5, k. 53.

${ }_{12}$ Potwierdzeniem są publikacje z okresu międzywojnia na temat KPP i jej poprzedników. Zob. T. Teslar, Przygotowania Kominternu do wybuchu rewolucji w Polsce, Warszawa 1931; A. Strapiński, Wywrotowe partie polityczne, Warszawa 1933; J.A. Reguła, Historia Komunistycznej Partii Polski w świetle faktów i dokumentów, Warszawa 1934; A.R. Keller, 
Jak przekonać społeczeństwo, że ci, których powszechnie uważano za zdrajców, byli w rzeczywistości patriotami?

Kontekst nadchodzących wyborów przysparzał Wydziałowi Propagandy oraz WHP dodatkowych trudności w tej materii. Z punktu widzenia liderów komunistycznych PPR musiała przecież spacyfikować aspiracje swojego sojusznika i de facto jedynego konkurenta, czyli PPS, z premierem Edwardem Osóbką-Morawskim na czele. Chociaż główne zadanie bieżącej propagandy politycznej stanowił zmasowany i otwarty atak na PSL, tj. partię, która od powrotu Stanisława Mikołajczyka do kraju latem 1945 r. budziła nadzieje wolnościowe olbrzymiej rzeszy Polaków, to za kulisami podejmowano równie aktywne działania w celu odpowiedniego usytuowania się w relacji do PPS ${ }^{13}$. Było to jedno z głównych zadań postawionych przed wykładowcami Centralnej Szkoły PPR już w 1945 r., prowadzącymi zajęcia poświęcone historii ruchu robotniczego w Polsce ${ }^{14}$.

W wyniku fatalnych dla komunistów rezultatów referendum, które ukazały, iż PPR nie jest w stanie zjednoczyć wokół siebie społeczeństwa, PPS złapała wiatr w żagle, coraz ostrzej domagając się wyrównania stosunku sił $\mathrm{w}$ aparacie państwowym ${ }^{15}$. Wysuwała nawet koncepcje samodzielnego pójścia do wyborów. W Biurze Politycznym PPR oraz w „szóstce partyjnej”, czyli międzypartyjnych spotkaniach kierownictw PPR i PPS, toczono żywe dyskusje co do formy połączenia obu partii. Z racji istotnych różnic programowych

KPP $i$ podlegte jej organizacje, czyli komunistyczne organizacje $w$ Polsce, Warszawa 1934; B. Słoński, Agentura Kominternu w Polsce, Warszawa 1937. Zob. też: K. Sacewicz, Centralna prasa Polski Podziemnej wobec komunistów polskich 1939-1945, Warszawa 2009, s. 78-83 i n.

${ }^{13}$ Ze względów ideologicznych i aby zapewnić hegemonię jedynej, według komunistów, partii marksistowsko-leninowskiej, dążono do tzw. zjednoczenia ruchu robotniczego, czyli wchłonięcia PPS, co nastapiło ostatecznie w grudniu $1948 \mathrm{r}$. W wymiarze praktycznym obawiano się ewentualnej koalicji PPS i PSL, możliwej po zdobyciu większości parlamentarnej w wyborach. PPS z kolei występowała przeciwko rozbiciu PSL, słusznie obawiając się całkowitego zawłaszczenia sceny politycznej przez komunistów. Na temat stosunków między PPR a PPS zob. m.in.: J. Holzer [W. Pański], PPS w latach 1944-1948, Warszawa 1985; L. Mielnicki, Skradzione sztandary PPS, Warszawa 1987; B. Barnaszewski, Polityka PPR wobec zalegalizowanych partii i stronnictw, Warszawa 1996; J. Żaryn, Ostatnia „legalna opozycja” polityczna $w$ Polsce 1944-1947, w: Polacy wobec przemocy 1944-1956, red. B. Otwinowska, J. Żaryn, Warszawa 1996; J. Wrona, System polityczny w Polsce 1944-1950. Miejsce - funkcje - relacje partii politycznych w warunkach budowy $i$ utrwalania systemu totalitarnego, Lublin 1997; R. Spałek, Między pragmatyzmem a zdrada. Zawłaszczenie PPS w kraju (1944-1948), w: Polska Partia Socjalistyczna. Dlaczego sie nie udało? Szkice. Wspomnienia. Polemiki, red. R. Spałek, Warszawa 2010, s. 145-242; J. Wrona, Polska Partia Robotnicza wobec partii i ugrupowań satelickich, w: Polska Partia Robotnicza 1944-1948..., s. 135-161.

${ }_{14}$ Protokół z posiedzenia Sekretariatu KC PPR odbytego w dniu 30 czerwca 1945 r., w: Protokoty posiedzeń Sekretariatu KC PPR 1945-1946, oprac. A. Kochański, Warszawa 2001, s. 69.

${ }_{15}$ Więcej zob. K. Kersten, Narodziny systemu wtadzy. Polska 1943-1948, Poznań 1990. 
mówiono o konieczności odpowiedniego przygotowania ideologicznego. Łączyło się to nieuchronnie z dyskusja nad ich dziedzictwem historycznym. Próby znalezienia wspólnej platformy w kontekście opisanej rywalizacji napotykały wiele trudności, zwłaszcza że towarzyszyła im świadomość, iż właśnie w kwestii niepodległości, tak głośno podnoszonej przez PPR, to PPS - nawet koncesjonowana - miała o wiele mocniejsze karty. Formalnie była spadkobierczynią stronnictwa, które przed wojna, w odróżnieniu od KPP, niezmiennie wskazywało odzyskanie i utrzymanie niepodległości kraju jako cel nadrzędny. PPS postulowała oparcie przyszłej zjednoczonej partii na jak najszerszych podstawach, obejmujących nie tylko dorobek marksizmu-leninizmu, ale również wszystkich europejskich partii robotniczych, w tym jej własny. Spotkało się to ze zdecydowanym sprzeciwem kierownictwa PPR, nie wyłączając Jakuba Bermana, który odgrywał kluczową rolę w procesie zjednoczeniowym $^{16}$. Rywalizacja między dwiema partiami robotniczymi PPR i PPS to oś sporu dyskusji w WHP, którą wzbudziło wystapienie Daniszewskiego. Sam zaś temat referatu - zagadnienie niepodległości - jest rdzeniem owej osi ${ }^{17}$.

Warto w tym miejscu wspomnieć kilka słów o samym WHP. Został powołany 23 V 1946 r. przez Sekretariat KC PPR i nie podlegał Wydziałowi Propagandy. Uznano bowiem, że ten ostatni niewiele do tego momentu zrobił w kwestii opracowania dziejów polskiego ruchu komunistycznego oraz że nie jest w stanie zapewnić mu odpowiedniej podbudowy teoretycznej ${ }^{18}$. Funkcję pierwszego dyrektora WHP pełniła Maria Turlejska. Dwa piony Wydziału, archiwalny oraz propagandowo-historyczny, współpracowały przy zbieraniu materiałów i opracowywaniu biografii działaczy PPR, zarówno na użytek wewnętrzny - w celu kształtowania kadr - jak i zewnętrzny ${ }^{19}$.

Autor referatu, Tadeusz Daniszewski urodził się w 1904 r. w Warszawie. Pochodził z inteligenckiej, zamożnej rodziny żydowskiej. Przed wojną był

${ }_{16}$ Więcej zob. A. Sobór-Świderska, Jakub Berman. Biografia komunisty, Warszawa 2009, s. 232 i n.

${ }_{17} \mathrm{~W}$ aktach zachowało się również trójstronicowe streszczenie przedstawiajace osiem tez zawartych w referacie Tadeusza Daniszewskiego, które dość wiernie oddają myśl autora. Nad poszczególnymi zdaniami tekstu odręcznie nadpisane sa pojedyncze słowa komentujące. Trudno przesądzić, kim był autor owego streszczenia oraz komentator. Notatki, z wyjątkiem pojedynczych słów, takich jak: „dlaczego”, „dyskusyjne”, „nie przypadek”, „nie”, trudno odcyfrować, tak ze względu na charakter pisma, jak i pewne skróty myślowe.

18 Protokół nr 12 posiedzenia Sekretariatu Komitetu Centralnego PPR z dnia 23 maja 1948 r., w: Protokoły posiedzeń Sekretariatu..., s. 255.

19 T. Rutkowski, Tworzenie zrębów mitu. Działalność Wydziału Historii Partii Komitetu Centralnego Polskiej partii Robotniczej na polu propagandy dziejów ruchu robotniczego, w: Polska Partia Robotnicza 1944-1948..., s. 262-274. Szerzej zob. P. Hübner, Nauka polska po II wojnie światowej. Idee i instytucje, Warszawa 1987; Cz. Lewandowski, Kierunki tak zwanej ofensywy ideologicznej $w$ polskiej oświacie, nauce i szkołach wyższych $w$ latach 1944-1948, Wrocław 1993; T. Rutkowski, Nauki historyczne w Polsce 1944-1970. Zagadnienia polityczne i organizacyjne, Warszawa 2008, s. 74-81. 
członkiem Komunistycznej Partii Robotniczej Polski, ZMK oraz KPP, gdzie pełnił liczne funkcje w aparacie kierowniczym. Aktywną działalność organizacyjną przerywały mu okresy spędzone w więzieniu oraz dłuższe wyjazdy do ZSRS, gdzie należał do WKP(b) i wykładał w szkole partyjnej. Pracował również w Komitecie Wykonawczym Kominternu. Wiosną 1943 r. mianowano go redaktorem głównym Rozgłośni Radiowej im. Tadeusza Kościuszki w Moskwie. Musiał cieszyć się niemałym zaufaniem władz sowieckich, skoro zwracano się do niego o opiniowanie potencjalnych członków Centralnego Biura Komunistów Polskich. Stalin, nieufny do krajowego kierownictwa partii, powołał ten ośrodek w styczniu $1944 \mathrm{r}$. Miał on z czasem przejać władzę w Polsce.

W chwili, gdy Daniszewski wygłaszał referat, pełnił funkcję dyrektora Centralnej Szkoły Partyjnej w Łodzi. Gdy dwa lata później, we wrześniu 1948 r. Maria Turlejska jako bliska współpracowniczka Gomułki została usunięta ze stanowiska kierownika WHP, zastapił ją właśnie Daniszewski. $\mathrm{W}$ grudniu tego samego roku został również wybrany na członka KC PZPR i pełnił tę funkcję do listopada 1968 r. Był niezwykle płodny, jeżeli chodzi o publikacje popularne oraz wykłady z historii ruchu robotniczego. Do $1956 \mathrm{r}$. bezpośrednio uczestniczył w wyznaczaniu głównych kierunków badań podejmowanych w Wydziale. Dostosowywał się przy tym całkowicie do wytycznych władz sowieckich. Uchodził za głównego cenzora historiografii tego okresu, odpowiedzialnego za przestrzeganie właściwej wykładni. Warto tutaj przypomnieć, że kiedy w 1957 r. zlikwidowano WHP, Daniszewski został odwołany m.in. pod zarzutem absurdalnie jaskrawych zafałszowań historii, majacych niewiele wspólnego z nauka historyczna ${ }^{20}$.

W omawianym referacie Tadeusz Daniszewski podją się „krytycznego oświetlenia” problemu niepodległości na „poszczególnych etapach rozwoju ruchu robotniczego". Cofnął się do początków ruchu robotniczego na ziemiach polskich. Wyodrębnił w nim dwa powstałe w latach siedemdziesiatych XIX w. nurty: „międzynarodowy”, zapoczątkowany przez Ludwika Waryńskiego i partię „Proletariat” oraz „narodowy”, wywodzacy się od Bolesława Limanowskiego ojca PPS. Zdaniem Daniszewskiego żaden z tych kierunków nie był wolny od „wypaczeń”, wyraźnie jednak zaznaczał, że nie można ich porównywać, tak co do natury, jak i znaczenia. W dłuższym wywodzie wykazywał, iż Waryński, negując sens walki o niepodległość, w rzeczywistości rozminą się z Marksem. W przekonaniu Daniszewskiego błąd ten wynikał z nadgorliwości oraz nadzwyczajnej troski o interesy proletariatu. Mimo to zdecydowanie wyżej ocenił „nurt międzynarodowy”. Przy wszystkich swoich przewinieniach był on przecież w swojej zasadniczej linii marksistowski - internacjonalistyczny

${ }^{20}$ AAN, KC PZPR, sygn. 237/XXIII-444, Akta osobowe Tadeusza Daniszewskiego; C. Budzyńska, Daniszewski Tadeusz, w: Stownik biograficzny działaczy polskiego ruchu robotniczego, red. F. Tych, t. I, Warszawa 1978, s. 391-392; B. Cichocki, K. Jóźwiak, Najważniejsze sa kadry. Centralna Szkoła Partyjna PPR/PZPR, Warszawa 2006, s. 56-57. 
i klasowy, a zatem stawiający dobro proletariatu ponad wszystko. Podkreślając w każdym niemal zdaniu niepodważalny - w mniemaniu Daniszewskiego patriotyzm członków „nurtu międzynarodowego”, potępiał ich jednocześnie za rezygnację z propagowania hasła walki o niepodległość jako niezgodne z wykładnią zarówno Marksa, jak i Lenina.

Kontynuacją owego błędu obciążył SKPiL oraz jej czołową przedstawicielkę - Różę Luksemburg. Tę ostatnią zgubiła wiara, że socjalizm jest remedium na wszystkie bolączki, lekceważenie problemu ucisku narodowego doświadczanego ze strony zaborców, niedocenienie wzrostu patriotyzmu w społeczeństwie oraz założenie, że sprawa odzyskania niepodległości pozostawia mieszczaństwo obojętnym. Wymienione przez autora przyczyny zostały zestawione ze soba jedna obok drugiej, bez odróżniania meritum od względów pragmatyczno-taktycznych. Innymi słowy: „nurt międzynarodowy” mylnie rozpoznał nastroje społeczne oraz „moment historyczny”. Nieco łaskawiej Daniszewski ocenił PPS-Lewicę, gdyz - jak zaznaczał - nie zrezygnowała ona całkowicie z hasła niepodległości, choć niestety - jak ubolewał - pod wpływem nacjonalizmu pepeesowskiego. Ma tu na myśli PPS-Lewicę powstałą w 1906 r., w reakcji na rewolucję rosyjską $1905 \mathrm{r}$.

W dalszej części referatu Daniszewski omówił to, co określał jako czwarty łańcuszek kierunku międzynarodowego, a mianowicie KPP, bezpośredniej spadkobierczyni SDKPiL oraz PPS-Lewicy. W swojej wypowiedzi posłużył się skrótem myślowym: w odniesieniu do okresu, kiedy to istniała KPRP, zastosował nazwę KPP. Powołując się na deklarację I Zjazdu KPRP z grudnia 1918 r., potępił odrzucenie przez nią haseł autonomii czy nawet samookreślenia narodu polskiego „w kontekście rozwoju form politycznych okresu kapitalistycznego" ${ }^{21}$. Innymi słowy, naród polski - według stanowiska KPP - nie miał prawa do samostanowienia, jeżeli w jego wyniku powstałoby państwo o ustroju kapitalistycznym. Po II Zjeździe w 1923 r. KPP zmieniła częściowo swój osąd, a całkowicie skorygowała go na IV konferencji grudniowej w 1925 r., doceniając kwestię istnienia państwa polskiego i jego niepodległości oraz powołując się na prawo do samookreślenia narodów. Niefortunnie jednak wystapiła również z propozycja przyłączenia Polski do republik sowieckich, co „przekreślało jej demokratyczny charakter". Co charakterystyczne, Daniszewski potępiał nie tyle samą chęć zjednoczenia ze Związkiem Sowieckim - ojczyzną rewolucji, co zamiar przeprowadzenia planu sprzecznego z wolą społeczeństwa. Posłużył się tu retoryką typową dla PPR, która od czasu okupacji deklarowała zamiar prowadzenia walki o „demokrację ludowa”. Hasło „dyktatury proletariatu” czy nawet walki o ustrój socjalistyczny odłożono w tym okresie na bok ${ }^{22}$.

${ }^{21}$ AAN, KC PPR, sygn. 295/XIX-12, k. 11.

${ }^{22} \mathrm{Na}$ temat retoryki stosowanej w tym okresie zob. M. Zaremba, Komunizm, legitymizacja, nacjonalizm. Nacjonalistyczna legitymizacja wtadzy komunistycznej w Polsce, Warszawa 2005, s. 135-150. Na temat narzędzi propagandowych zob. Polska pod reżimem komuni- 
Daniszewski potępił stanowisko wobec „ucisku narodowego” na Górnym Ślasku i Pomorzu, zajęte w 1927 r. na IV Zjeździe partii ${ }^{23}$. Nie uzasadnił tego jednak w żaden szczególny sposób. Stworzyło to wrażenie, że jego zdaniem takie stanowisko było po prostu nierozsądne ze względów taktycznych i wizerunkowych.

Ostatni, ale i fundamentalny zarzut postawiony partii przez Daniszewskiego okazał się również natury taktycznej. Chodziło o oddanie „wrogowi klasowemu" inicjatywy walki o niepodległość. W konsekwencji KPP - jak stwierdził autor - sama sobie była winna, że społeczeństwo postrzegało ją jako partię reprezentująca interesy obcego państwa. Konkludując, Daniszewski wyraźnie podkreślił, że choć na głoszenie postulatu niepodległości moment historyczny, jak ujmowali to marksiści, nie zawsze był odpowiedni, nigdy nie należało go tracić z pola widzenia. „Nurt międzynarodowy” nie powinien także rezygnować z prób przekonywania społeczeństwa, że to właśnie wspólna walka $\mathrm{z}$ proletariatem państw zaborczych jest $\mathrm{w}$ stanie zapewnić Polsce niepodległość. I tak podczas wojny polsko-sowieckiej partia, zdaniem autora, nie umiała dotrzeć do społeczeństwa z przekazem, iż Armia Czerwona w niczym nie zagrażała niepodległości Polski. Jak tłumaczył, jedynie pragnienie odrzucenia retoryki nacjonalistycznej powodowało, iż KPP unikała w tym okresie używania przymiotnika „polski”.

Daniszewski stanowczo zaprzeczał, aby wymienione powyżej wypaczenia KPP mogły być wynikiem mankamentów w założeniach programowych. Utrzymywał, iż za „sianie ideologicznego zamętu” odpowiadały, według wszelkiego prawdopodobieństwa, ,agenci piłsudczyzny”. O żarliwości uczuć patriotycznych kapepowców miał świadczyć zaś fakt, iż w 1934 r. bili oni na alarm przed nadpływająca fala „faszyzmu”, zagrażająca niepodległości Rzeczypospolitej, jak i ich ofiarność podczas wojny. Przywołał w tym miejscu postać Mariana Buczka, wykreowanego już wówczas na symbol spontanicznego poświęcenia się dla ojczyzny. Po zwolnieniu z sanacyjnego więzienia we wrześniu 1939 r. Buczek rzekomo przedzierał się bohatersko, by walczyć w obronie oblężonej Warszawy. Dalej Daniszewski wymienił cały poczet postaci „nurtu międzynarodowego", w tym działacza SDKPiL, Marcina Kasprzaka straconego na cytadeli za zbrojną obronę drukarni, Władysława Hibnera, Władysława

stycznym. Sprawozdanie z sytuacji w kraju (1944-1949), wstęp i oprac. J. Mysiakowska-Muszyńska, W. Muszyński, Warszawa 2015, s. 142-146.

${ }^{23}$ Obrady IV Zjazdu KPP odbyły się w Moskwie i trwały aż cztery miesiące. Warto zaznaczyć, że w wyniku zaciętej walki frakcyjnej stery partyjne przejęła tzw. grupa mniejszościowa (grupa Juliana Leszczyńskiego), wspierana przez Stalina. Całkowicie odstapiono od linii partii w kwestii niepodległości Polski nakreślonej w latach 1923 i 1925, wysuwając hasło Polskiej Republiki Radzieckiej. Stwierdzono, że postulat samookreślenia aż do oderwania należało wysunać do Górnego Śląska. Zalecano przy tym zwalczanie tam „terroru nacjonalistycznego stosowanego przez rząd faszystowski i jego zbrojne kadry powstańców górnośląskich”. Szerzej zob. H. Cimek, Komuniści..., s. 67-68. 
Kniewskiego oraz Henryka Rutkowskiego - działaczy komunistycznych skazanych na śmierć za próbę zabójstwa Józefa Ciechanowskiego, który został zidentyfikowany jako agent policji. Ludwika Waryńskiego określił natomiast mianem „prekursora apelu o walkę z caratem” ${ }^{24}$. Według prelegenta wszyscy oni walczyli o „lepsze jutro ludu polskiego” ${ }^{25}$. Czyny zaś - konkludował - sa ważniejsze od haseł.

Następnie Daniszewski przeszedł do omówienia tzw. nurtu narodowego. Choć założeniem tego kierunku było połączenie walki o wyzwolenie narodowe $\mathrm{z}$ wyzwoleniem socjalnym, w praktyce „zaciera on momenty klasowe, narusza zasady solidarności międzynarodowej, schodzi na manowce nacjonalizmu" ${ }^{26}$. Wina za zaniechanie przeprowadzenia analizy marksistowskiej oraz podporządkowanie wyzwolenia socjalnego wyzwoleniu narodowemu obarczał już Bolesława Limanowskiego. Od początków powstania „nurtu narodowego" największym jego grzechem było jednak odcięcie się od Rosji, zwłaszcza w okresie rewolucji 1905 r. Zamiast wierzyć, iż „zjednoczenie się" z robotnikami rosyjskimi przyniesie wyzwolenie (autor nie precyzował tu, o jakie wyzwolenie chodzi), postawiono na wyzwolenie narodowe, osiagnięte w wyniku wojny jednego z zachodnich mocarstw „imperialistycznych” z Rosja.

Winę za zdominowanie PPS przez działaczy „nurtu narodowego” ponosił, zdaniem Daniszewskiego, Józef Piłsudski. Traktował on bowiem ruch robotniczy w instrumentalny sposób, jako „narzędzie do celów burżuazyjnych”27. Autor podkreślił jednak, iż nie wolno patrzeć na całą tradycję pepesowska jako na przejaw „nacjonalizmu burżuazyjnego”. Powstanie PPS-Lewicy w następstwie rozłamu z 1906 r. - w opozycji do frakcji rewolucyjnej Piłsudskiego - ocenił jako „zdrową reakcję dołów” partyjnych. Odnosząc się do PPS-Frakcji Rewolucyjnej (traktowanej jako skrzydło prawicowe PPS), mocno przeciwstawił „szowinistyczną" górę stronnictwa szeregowym członkom partii. Według niego zarówno oni, jak i szeregowi legioniści poświęcali swoje życie w przekonaniu, że walczą o „niepodległą Polskę socjalistyczną”, a nie o „niepodległość burżuazyjną". Bezpardonowo potępił natomiast samą ideę przyświecająca stworzeniu Legionów, jako służbę niemiecko-austriackiemu imperializmowi.

Dodatkowy „wstyd i hańbę” - kontynuował Daniszewski - przynieśli PPS działacze, którzy po wojnie współtworzyli „faszyzm sanacyjny”. Oprócz Piłsudskiego wymienił także Aleksandra Prystora, Kazimierza Sosnkowskiego, Wacława Jędrzejewicza, Jędrzeja Moraczewskiego, Rajmunda Jaworowskiego, Ignacego Mościckiego i Tytusa Filipowicza. Konstatował: „Kiedy więc odrodzona PPS przypomina dziś na każdym kroku swe «54 lat walki o niepodległość», to my, nie negujacc dawnych zasług PPS, zwłaszcza jej dolnych ogniw, w walce

\footnotetext{
${ }^{24}$ AAN, KC PPR, sygn. 295/XIX-12, k. 16.

${ }^{25}$ Ibidem.

${ }^{26}$ Ibidem.

${ }^{27}$ Ibidem, k. 18.
} 
przeciw caratowi, musimy wskazać bratniej partii i na odwrotna stronę medalu, na to mianowicie, do jakich konsekwencji doprowadziła klika piłsudczykowska wewnątrz PPS i jak to fatalnie zaciążyło na dziejach tej partii" 28 .

Na zakończenie Daniszewski zdobył się na ogólną refleksję nad istotą PPR i jej zakotwiczeniem w tradycji. Przedstawił ja jako partię, która potrafiła połaczyć najlepsze tradycje obu nurtów: walki o niepodległość oraz o wyzwolenie społeczne. Określił ją mianem „syntezy”.

Analizując treść wypowiedzi Daniszewskiego, widać, że kluczowym elementem jego narracji jest oczywiście przedstawienie ewolucji ideowej, która przeszła polska partia komunistyczna. Stwierdził wprawdzie, iż z chwilą odzyskania przez Polskę niepodległości, komuniści, którzy zawsze byli patriotami, popełnili błąd, negując rację bytu Polski. Traktowali ją jako państwo o ustroju kapitalistycznym, nie doceniając wartości, jaką stanowiła niepodległość sama w sobie. Popełnili ten błąd, ponieważ bezwzględnie najważniejszy był dla nich prymat „dobra ludu”. Jego zdaniem naprawili go jednak podczas II Zjazdu partii w 1923 r. Od tej pory, aż do współczesności, mieli być niewzruszenie gorącymi obrońcami niepodległości państwa polskiego ${ }^{29}$.

Rzuca się w oczy osobliwa specyfika tego wywodu. Daniszewski odcią całkowicie dzieje i wybory polityczne KPP, w tym jej stanowisko wobec kwestii polskiej niepodległości, od strategii Kominternu, a ściśle mówiąc - od wytycznych WKP(b). O zjazdach Międzynarodówki Komunistycznej i przyjętych przez nią rezolucjach nie ma w referacie nawet słowa. Radykalna reorientacja, do której doszło na II Zjeździe partii, powstała jakby w zupełnej próżni, w oderwaniu od ustaleń IV Kongresu Międzynarodówki Komunistycznej z końca 1922 r. W wyniku klęski poniesionej w wojnie polsko-bolszewickiej oraz porażki ruchu rewolucyjnego w Niemczech na zjeździe tym przyjęto strategię dwuetapowej rewolucji. Stąd rezygnacja z haseł „dyktatury proletariatu” i innych radykalnych postulatów.

Podczas V Kongresu Międzynarodówki Komunistycznej z 1924 r. pozycję dominująca w ruchu komunistycznym zyskał nurt ultralewicowy. W przyjętej wówczas uchwale stwierdzono, iż Polska jest państwem imperialistycznym stanowiącym narzędzie „sił kontrrewolucyjnych”. W konsekwencji strategii przyjętej przez ten ostatni kongres Kominternu, na III Zjeździe KPRP z 1925 r. odrzucono uchwały poprzedniego zjazdu jako „nacjonalistyczne”30. Doszło zatem do kolejnej radykalnej wolty. Jednak Daniszewski, chwaląc rzekoma

28 Ibidem, k. 22.

${ }^{29} \mathrm{Na}$ temat stosunku kapepowców do niepodległości Polski zob. K. Trembicka, Środowisko komunistów wobec odzyskania niepodległości przez Polskę $i$ wojny polsko-bolszewickiej, w: Komuniści w międzywojennej Warszawie..., s. 43-65.

${ }^{30} \mathrm{Na}$ temat zależności KPP od Kominternu zob. m.in.: H. Cimek, KPP wobec drugiej Rzeczypospolitej (1918-1938), Warszawa 1988; R. Nazarewicz, Komintern a lewica polska. Wybrane problemy, Warszawa 2008; P. Gontarczyk, Polska Partia Robotnicza. Droga do władzy (1941-1944), Warszawa 2006, s. 20-59. 
przemianę komunistów w 1923 r., nie wspomniał o zwrocie, który nastapił dwa lata później. Warto w tym miejscu przytoczyć pamiętniki Gomułki, który wiele lat potem dobitnie podsumował oficjalne stanowisko KPRP i KPP wobec kwestii niepodległości Polski. Pisał: „Od tego czasu, aż do rozwiązania KPP, we wszystkich jej uchwałach, nawet w tych, które mówią o niepodległości Polski, znajdujemy jedynie hasło walki o Polską Republikę Radziecką"31.

Stworzenie przez Daniszewskiego pozorów, iż KPP działała autonomicznie i w nieskrępowany sposób, dokonywała gruntownej rewizji swoich poglądów, jest szczególnie widoczne przy poruszonej przez niego kwestii Ślaska i Pomorza. Biorac pod uwage powstała po wojnie nowa sytuacje geopolityczna, nie mógł całkowicie jej przemilczeć. W istocie włączenie w $1932 \mathrm{r}$. przez KPRP do swojego programu prawa samookreślenia ludności Górnego Śląska i Pomorza, prowadzące do oderwania od Polski, a także prawo Gdańska do ponownego złączenia z Niemcami, w oczach społeczeństwa kompromitowały ją w szczególny sposób. Tym bardziej że nastapiło to rok po dojściu Hitlera do władzy. Według narracji Daniszewskiego „błąd” ten był jedynie wypadkiem przy pracy i w niczym nie odzwierciedlał stosunku partii komunistycznej do państwa polskiego. W rzeczywistości stanowisko KPP stanowiło wierny obraz pozycji Kominternu, który planował podarować przyszłym rewolucyjnym Niemcom rozszerzenie ich wschodnich granic kosztem Polski. Z tego powodu już na IV Zjeździe KPP wysunęła postulat samookreślenia Ślaska ${ }^{32}$.

Kolejnym aspektem historii ruchu robotniczego, poruszonym przez Daniszewskiego, była kwestia oceny dorobku PPS. Należy w tym miejscu dodać, że jego referat wpasowywał się w ramy dyskusji zapoczątkowanej przez Gomułkę podczas I Zjazdu PPR w grudniu 1945 r., podczas której poddał on wizję dziejów ruchu robotniczego ponownej krytycznej ocenie. Daniszewski kilkakrotnie powoływał się na to przemówienie. Odniósł się również do wystąpień tow. Wiesława na XXVI Kongresie „odnowionej” PPS, którego obrady trwały w Warszawie od 29 VI do 1 VII 1945 r. Padły wówczas następujące słowa: „Oba prady polskiego ruchu robotniczego, nurt PPR i PPS winny ze sobą ściśle współpracować. Nauczyła nas wiele historia, wiele nauczyło życie. PPR uznaje cenny wkład PPS do wspólnej walki, a przede wszystkim jej zdrowe patriotyczne tradycje. W PPS coraz więcej zrozumienia znajdowała rola Związku Radzieckiego oraz konieczność zbliżenia z naszym wielkim wschodnim sasiadem" ${ }^{33}$. Daniszewski podążał torem nakreślonym przez I sekretarza, przy wszystkich wymienionych powyżej zastrzeżeniach uznając zasługi PPS dla walki o niepodległość Polski.

Po referacie wygłoszonym przez Daniszewskiego na forum WHP odbyła się dyskusja. Wzięło w niej udział aż 35 uczestników. Nie było wśród nich

\footnotetext{
${ }^{31}$ W. Gomułka, Pamiętniki, t. I, Warszawa 1994, s. 374.

${ }^{32}$ H. Cimek, Komuniści..., s. 82-92; P. Gontarczyk, op. cit., s. 28-30.

${ }^{33}$ AAN, KC PPR, sygn. 295/XIX-12, k. 29.
} 
jednak członków Komisji Historycznej powołanej do konsultacji książki Daniszewskiego - Franciszka Fiedlera, Ostapa Dłuskiego i Reginy Kobryńskiej. Zachowany stenogram pozwala stwierdzić, że głos zabrali: Jakub Berman, Roman Werfel, Jerzy Tepicht, Kamila Kancewiczowa, Stefan Jędrychowski, Artur Starewicz, Józef Kowalski, Adolf Starzec, Adam Schaff, Józef Kratko, Feliks Stoliński i Władysław Bieńkowski ${ }^{34}$. Wszyscy byli przed wojna zasłużonymi działaczami komunistycznymi. Tepicht, Jędrychowski, Werfel oraz Bieńkowski należeli do czołowych publicystów PPR.

$\mathrm{Z}$ owych nazwisk kluczowa jest postać Bermana, ze względu na jego ówczesne wpływy polityczne, odpowiedzialność za kwestie ideologiczne w Biurze Politycznym KC oraz fakt, że obok Bolesława Bieruta oraz Hilarego Minca został jednym z głównych zwycięzców walki frakcyjnej w 1948 r. ${ }^{35}$

Przy lekturze tekstu uwidacznia się przede wszystkim emocjonalność reakcji większości audytorium na wystapienie Daniszewskiego. Rozważania taktyczne dotyczące przedstawienia społeczeństwu spójnej narracji zeszły na dalszy plan. Marks, Engels i Lenin byli nader często przywoływani jako niepodważalne autorytety. Dyskutanci nieustannie przerzucali się cytatami z Lenina, Luksemburg, Feliksa Dzierżyńskiego i Juliana Marchlewskiego, usiłując przekonać siebie nawzajem co do słuszności interpretacji tej czy innej kwestii. Zaskakujące może się wydawać to, że Stalin wzmiankowany jest jedynie raz. Zauważmy, iż przytaczanie poglądów tzw. klasyków marksizmu-leninizmu niewiele wnosiło do linii propagandowej zakładającej maskowanie związków z komunizmem.

Próbę pogodzenia wiary w nieomylność partii komunistycznej z zaprzeczająca jej rzeczywistościa podjęły w niezamierzony, komiczny sposób dwie osoby. Celina Bobińska postulowała, aby nie odtwarzać historii ruchu robotniczego na podstawie rezolucji ${ }^{36}$. Wszak historia (i tu nie obyła się bez cytatu z Lenina)

${ }^{34}$ Pozostałymi uczestnikami dyskusji byli m.in.: Władysław Bieńkowski, Celina Budzyńska, Bolesław Druker, Teodora Feder, Romana Granas, Irena Groszowa, Józef Kapliński, Zenon Kliszko, Żanna Kormanowa, Helena Kozłowska, Pelagia Lewińska, Franciszek Mazur, Mieczysław Mietkowski, Władysław Wolski i Franciszek Zubrzycki.

35 Jakub Berman (1901-1984), prawnik. Członek KPP (od 1928). Podczas II wojny światowej w ZSRS. Kierownik polskiej grupy w szkole Kominternu w Kusznarenkowie (1941-1943), członek redakcji Radiostacji „Kościuszko” w Moskwie (1943), organizator i członek CBKP, zastępca kierownika Resortu Spraw Zagranicznych PKWN (1944), członek Sekretariatu KC PPR (XI-XII 1948), a następnie Sekretariatu KC PZPR (XII 1948 - III 1954), członek Komisji Biura Politycznego KC PZPR ds. MBP (1949-1956), członek Prezydium Rządu (V 1950 - XI 1952), wiceprezes Rady Ministrów (III 1954 - V 1956). W 1957 r. wydalony z KC PZPR. Od 1957 do 1968 r. pracownik redakcji historycznej Spółdzielni Wydawniczej „Książka i Wiedza”. W 1984 r. wykluczony z partii. Więcej zob. T. Mołdawa, op. cit., s. 336; A. Sobór-Świderska, op. cit., Warszawa 2009.

${ }^{36}$ Celina Bobińska (1913-1997), córka pisarki Heleny Bobińskiej z d. Brun oraz działacza komunistycznego Stanisława Bobińskiego, historyk dziejów nowożytnych. W 1918 r. wyjechała z matka do Rosji, gdzie ukończyła studia wyższe i pracowała na uniwersytecie 
to, jej zdaniem, nie ciag dokumentów, lecz dzieje poszczególnych działaczy. Wtórował jej Władysław Bieńkowski, który stwierdził, że powoływanie się na hasła z przeszłości może stać się „źródłem nieporozumień i kłótni o znaczenie słów [...] «Proletariat nie ma ojczyzny» [jest to słynne hasło Ludwika Waryńskiego - K.L.] to typowy przykład zdania metaforycznego" ${ }^{37}$.

Pomijając kilka głosów, które rzeczowo skupiały się na kwestii opracowania skutecznej propagandy, większość w oczywisty sposób emocjonowała się ideami. Udowodnienie patriotyzmu polskiej partii komunistycznej na przestrzeni dziejów stanowiło fundamentalna potrzebę chwili. Nie ma tu rozbieżności między retoryką stosowaną na zewnątrz a językiem kręgów wewnętrznych. Nie miejsce tu na rozstrzyganie, na ile spowodowane było to potrzebą uwiarygodnienia się w oczach społeczeństwa, a na ile wynikało z wewnętrznego przekonania poszczególnych dyskutantów. Wymagałoby to uprzedniego zdefiniowania pojęcia patriotyzmu. Trudno jednak nie założyć, iż doświadczenie okupacji, konfrontacja z zewnętrznym wrogiem (nawet jeżeli identyfikowanym jedynie z Niemcami) mogły odcisnąc swoje piętno na pojmowaniu sensu wspólnoty narodowej. Jednak badany materiał jest zbyt ograniczony, aby wysuwać tego typu wnioski. Niewattpliwie polemika, która referent wywołał, przypominała walkę z niewidzialnym wrogiem dyskutanci po kolei odpierali zarzut braku patriotyzmu, choć przecież ten ani razu nie padł.

Inna konstatacja, jaka się narzuca, to ogromna niechęć ogółu zgromadzonych do krytyki „nurtu międzynarodowego”, poczynając już od SDKPiL. Uzmysławia to siłę emocjonalnej identyfikacji z partia, rozwiązana 28 lat wcześniej. Józef Kowalski obstawał przy zdaniu, iż „nurt międzynarodowy” w przeszłości błędów nie popełniał, a jedynie przystosowywał się „dialektycznie" do sytuacji ${ }^{38}$. Wszyscy pozostali zapewniali, iż żadną miarą nie negowali

moskiewskim. Członek Komsomołu i ZPP (1943-1945). Powróciła do Polski w maju 1945 r. i wstapiła do PPR, a następnie do PZPR. W latach 1945-1950 pracowała jako publicystka i wykładowczyni w Centralnej Szkole Partyjnej. Kierownik Katedry Historii Polskiej na UJ (1950), profesor nadzwyczajny (1954), profesor zwyczajny (1961), kierownik Pracowni Badań Agrarnych w IH PAN. Więcej zob. T. Rutkowski, Nauki historyczne..., s. 95.

${ }^{37}$ AAN, KC PPR, sygn. 295/XIX-15, k. 63. Władysław Bieńkowski (1906-1991), filozof, publicysta. W okresie międzywojennym działacz komunistyczny. Podczas II wojny światowej nauczał we Lwowie (1939-1941), a następnie działał w konspiracji. Członek PPR (1942), współzałożyciel KRN, członek KC PPR (1945-1948), podsekretarz stanu w Ministerstwie Oświaty (1945-1956), kierownik Wydziału Propagandy KC PPR (1946-1947), członek Sekretariatu KC PPR (I-X 1948), dyrektor Biblioteki Narodowej w Warszawie (1948-1956), minister oświaty (1956-1959). W 1970 r. wykluczony z partii. Więcej zob. T. Mołdawa, op. cit., s. 337.

38 Józef Kowalski (1904-1986), publicysta, historyk ruchu robotniczego. Członek KPZU (od 1926), KPZB (od 1928), KPP (od 1933), WKP(b) (od 1940). Podczas II wojny światowej pracownik redakcji pism: „Wolna Praca” w Grodnie i „Sztandaru Wolności” w Mińsku, wykładowca w szkole MK, zastępca kierownika Rozgłośni Radiowej im. Tadeusza Kościuszki, 
popełnienia błędów przez SDKPiL. Usiłowali jednocześnie znaleźć, jeśli nie kontrargumenty, to przynajmniej okoliczności łagodzace dla tej partii, by ostatecznie przypuścić atak na PPS.

Owe okoliczności łagodzące zostały uprzednio przedstawione przez samego Daniszewskiego. Jest to więc swoisty dialog słyszącego z głuchymi. I tak Tepicht wyważał otwarte drzwi, pouczając Daniszewskiego, iż w „nurcie międzynarodowym" po prostu inaczej rozumiano kwestię wyzwolenia narodu polskiego niż w PPS ${ }^{39}$. Łączono ją mianowicie z rewolucją proletariacka. Jędrychowski twierdził z oburzeniem, że SDKPiL, a za nią KPP nigdy nie były „międzynarodowe”, lecz „internacjonalistyczne” ${ }^{40}$. Istota tego rozróżnienia jest dla współczesnego odbiorcy trudna do uchwycenia. Być może po prostu bardziej kładzie ono nacisk na ideę współpracy z rosyjską klasą robotniczą w imieniu wspólnych interesów. Według Jędrychowskiego wszelkie ich „wypaczenia” wynikały z wpływów obcej ideologii. W wypadku SDKPiL winę ponosił panujący ówcześnie „pozytywizm burżuazyjny”, bojkotujący aktywną walkę o niepodległość.

W ślad za Jędrychowskim wypowiadał się Werfel ${ }^{41}$. Podpierając się wybranymi cytatami z Luksemburg, zaklinał się, iż nie można zarzucić SDKPiL nieprzychylnej postawy wobec problemu niepodległości. Rozbieżności z PPS dotyczyły jedynie obranej strategii. Chodziło o dokonanie wyboru pomiędzy

zastępca kierownika redakcji „Polpress” ZPP (od 1944), kierownik moskiewskiego oddziału PAP (1945-1951). Do 1951 r. obywatel ZSRS i członek WKP(b), brał jednak udział w I Zjeździe PPR (XII 1945) i w Zjeździe Zjednoczeniowym PPR i PPS (XII 1948); formalnie stał się członkiem PZPR w 1951 r. Zastępca kierownika Zakładu Historii Partii KC PZPR (1951-1968); kierownik katedry historii PZPR w Instytucie Nauk Społecznych przy KC PZPR (1952-1954). Więcej zob. W. Bułat, Kowalski Józef, w: Stownik biograficzny..., t. III, s. 366; T. Rutkowski, Nauki historyczne..., s. 420.

39 Jerzy Tepicht (1908-1973), członek KZMP (1925-1930), KPP (1931-1935), KPF (19361945), PPR (1946-1948), PZPR (1948-1973), zastępca kierownika w wydziale rolnym przy KC PPR i KC PZPR (II 1947 - I 1951), zastępca członka KC (XII 1948 - VI 1964). Zob. http://katalog.bip.ipn.gov.pl/informacje/41731 (dostęp: 19 V 2017).

40 Stefan Jędrychowski (1910-1996), prawnik i ekonomista. Przed II wojną światową związany z lewicowymi organizacjami współpracującymi z KPP. Podczas II wojny w ZSRS. Działacz ZPP, organizator 1 Dywizji Piechoty im. T. Kościuszki, kierownik Resortu Informacji i Propagandy PKWN i pełnomocnik PKWN w Moskwie (VII-XII 1944), wiceprezes Centralnego Urzędu Planowania (1948-1949), zastępca przewodniczącego Państwowej Komisji Planowania Gospodarczego (1949-1951), minister spraw zagranicznych (1968-1971), minister finansów (1968-1974), ambasador PRL w Budapeszcie (1975-1978). Szerzej zob. T. Mołdawa, op. cit., s. 365-366.

${ }^{41}$ Roman Werfel (1906-003), działacz komunistyczny. Członek KZMP (od 1921), KPCz (od 1924), KPA (1924-1928), funkcjonariusz KPP (1928-1936). W czasie II wojny światowej w ZSRS (m.in. redaktor „Czerwonego Sztandaru”, „Nowych Widnokręgów” i „Wolnej Polski”). Członek PPR (1944), a potem PZPR, kierownik Spółdzielni Wydawniczej „Książka i Wiedza”, redaktor naczelny „Nowych Dróg” (1952-1955, 1956-1959), „Trybuny Ludu” (1955-1956), „Gazety Robotniczej” (1959-1960), zatrudniony w Pracowni/ Zakładzie Historii Stosunków Polsko-Radzieckich PAN. Usunięty z PZPR w 1968 r. Zob. http://katalog.bip. ipn.gov.pl/informacje/19629 (dostęp: 19 V 2017); T. Rutkowski, Nauki historyczne..., s. 81. 
wykorzystaniem konfliktu dzielącego mocarstwa imperialistyczne a oparciem się na ogólnoeuropejskiej rewolucji klas uciskanych. Drugi kierunek działań jedynie odkładał w czasie perspektywę odzyskania wolności i wyzwolenie narodowe. Miał je przynieść ostatecznie socjalizm. Z równym przekonaniem zabrał głos Feliks Stoliński: „Nie można przylepiać I proletariatowi etykietki kosmopolityzmu na podstawie jednej wypowiedzi Waryńskiego" ${ }^{42}$.

Wszyscy uczestnicy dyskusji, ustosunkowując się do sprawy narodowej w zależności od „interesów proletariatu”, zarzucali Daniszewskiemu prezentyzm, ahistorycyzm i brak marksistowskiego myślenia dialektycznego. Ich zdaniem zarzucenie hasła walki o niepodległość w danym momencie historycznym nie oznaczało wszak podważania sensu niepodległości w ogóle. Jałowość tych zastrzeżeń polegała na tym, iż Daniszewski mówił dokładnie to samo. Wskazywał jedynie, że „nurt międzynarodowy” rozmijał się niekiedy z momentem historycznym.

Dyskusja świetnie ukazuje jedna z podstawowych osi podziału wśród byłych kapepowców, która od początków funkcjonowania partii dzieliła ich w zasadniczy sposób. Różnica ta sprowadzała się do nadążania lub nie za zmianami w obranej przez Komintern taktyce. Tak jak nie wszyscy kapepowcy zorientowali się w odpowiednim momencie, na czym polegała zmiana strategii Międzynarodówki, dotycząca tworzenia frontów ludowych, mająca miejsce w 1934 r., tak i znacząca ich część nie była w stanie oswoić się z powrotem do niej w $1943 \mathrm{r}$.

Cytując Andrzeja Werblana, w 1946 r. „spora część aktywu i członków KPP cofnęła się ku poprzedniemu etapowi rozwoju ideologicznego"43. Głoszenie haseł „demokracji ludowej”, współpracy z socjalistami i ludowcami, obranie ewolucyjnych przemian społeczno-gospodarczych w kierunku socjalizmu oraz odłożenie radykalnych haseł było zgodne z założeniami opracowywanymi przez CBKP, a konkretnie Bermana. Obranie tej retoryki i tego kursu po wojnie spotkało się wprawdzie ze zrozumieniem kierownictwa PPR, ale wywoływało głęboką niechęć i niezrozumienie u znacznej części działaczy partii. Zwłaszcza przedwojenni komuniści odbierali tę drogę jako zdradę ideologii ${ }^{44}$. Zamiast tego wielu z nich chciało szybkiego wprowadzenia zmian na wzór Związku Sowieckiego. Owe wstecznictwo i odchylenia - posługiwanie się nieaktualnymi hasłami politycznymi - były piętnowane jako sekciarstwo. W 1946 r. uporczywe domaganie się przekształcenia Polski w republikę sowiecką i odrzucenie retoryki narodowo-niepodległościowej przez byłych kapepowców stanowiło

\footnotetext{
${ }^{42}$ AAN, KC PPR, sygn. 295/XIX-5, k. 54. Jerzy Stoliński (1903-1977), członek ZMK (1921), KPRP, KPP (1923), PPR (od 1943), PZPR (od 1948), wykładowca szkoły partyjnej przy KC PZPR, wykładowca polityki agrarnej i ekonomii politycznej na Wydziale Rolnym UMCS, pracownik IER (1950-1957). AAN, ANS, 97/327 i 42/212.

${ }^{43}$ A. Werblan, Klasowe i narodowe aspekty myśli politycznej PPR i PZPR, Warszawa 1987, s. 51.

${ }^{44}$ Szerzej zob. K. Kersten, op. cit., s. 157.
} 
największe możliwe przewinienie i skutkowało usuwaniem ze stanowisk partyjnych $^{45}$. Żaden $\mathrm{z}$ uczestników omawianej dyskusji tak daleko się nie posunął, ale sama niechęć do krytyki „nurtu międzynarodowego” narażała właśnie na ów zarzut, o czym przypominali niejednokrotnie Berman i Daniszewski podczas zebrania.

Odpowiadający na zarzuty dyskutantów prelegent podtrzymywał swoje tezy. Poza wytykaniem oponentom nieścisłości i rzekomych korekt, będących w rzeczywistości powtórzeniem jego słów, atakował ich za negowanie błędów w przeszłości. Nadgorliwym obrońcom SDKPiL Berman wypominał „bałwochwalczy pietyzm", stanowiący konsekwencję konfliktu z PPS. Postawę ich charakteryzował jako „sekciarska”. Było to sięgnięcie po broń ostateczna, z której jednak, jak już wspominałam, chętnie korzystano.

$\mathrm{Z}$ tej perspektywy szczególnie drażliwy temat stanowiła ocena KPP. W odróżnieniu od SDKPiL nikt się nie palił do obrony jej dobrego imienia, choć wszyscy wymienieni dyskutanci do partii tej należeli. Koncentrowali się na usprawiedliwianiu całego „nurtu międzynarodowego”. Kiedy z kolei odnosili się do jego błędów, nigdy nie brali pod uwagę tych stricte kapepowskich. Ta wewnętrzna cenzura nie była oczywiście przypadkowa. Przypomnijmy, iż do rozwiązania partii doszło w sierpniu 1938 r. pod pretekstem całkowitego spenetrowania jej przez polska policję. Zrehabilitowano ją dopiero w lutym $1956 \mathrm{r}$.

Chociaż problematyka związana z KPP była praktycznie nieobecna w dyskusji, wyjątek stanowiły dwa, całkowicie zresztą rozbieżne, głosy: „sekciarski” i „pragmatyczny”. Kamila Kancewiczowa domagała się, nie wiadomo co prawda z jaka intencja, poruszenia tematu rozwiazania KPP oraz dalszych losów jej członków ${ }^{46}$. Postawiony przez nią postulat nawiązywania do działalności niedobitków partii świadczy o całkowitym rozminięciu się z obraną linia propagandy. Wszak grupa do spraw polskich, powołana przez kierownictwo MK (po rozwiąaniu KPP) i kierowana przez Bolesława Mołojca, uznała za błąd wysuwanie hasła obrony niepodległości Polski oraz nawoływała do zaprowadzenia w Polsce władzy sowieckiej. Tymczasem Kancewiczowa ubolewała nad potencjalną możliwością zakwestionowania ciagłości walki jej towarzyszy partyjnych, oświadczajacc z moca: „nie może być tak, że nas nie było” ${ }^{4}$.

Zupełnie inny wydźwięk miała wypowiedź Bermana. Uznajacc konieczność przeprowadzenia samokrytyki, odniósł się do błędów popełnionych przez KPP.

\footnotetext{
${ }^{45}$ A.L. Sowa, Historia polityczna Polski 1944-1991, Kraków 2011, s. 115.

${ }^{46}$ Kamila Kancewicz (1879-1952), doktor medycyny. Członek PPS (od 1904), WKP(b) (od 1906), KPRP (od 1919), KPP (od 1923). Wyemigrowała do ZSRS w 1930 r. Aresztowana przez NKWD w okresie wielkiej czystki i więziona do 1944 r. W 1945 r. powróciła do Polski i wstapiła do PPR, a następnie do PZPR. Inspektor w Biurze Kontroli przy Prezydium KRN (później w NIK), wicedyrektor Państwowego Instytutu Higieny Psychicznej w Warszawie (1948-1952). Więcej zob. J. Kancewicz, Horwitz-Kancewiczowa Kamilia, w: Stownik biograficzny..., t. III, s. 556.

${ }^{47}$ AAN, KC PPR, sygn. 295/XIX-5, k. 52.
} 
Przypisywał je po części obecności prowokatorów zasiadających w kierownictwie ugrupowania, nawiązując tym samym do narracji Międzynarodówki z 1936 r. Jej kierownictwo obwiniło wówczas kolejnych przywódców partii o zaniedbania, w wyniku których do jej szeregów przeniknęli agenci winni powstania wizerunku partii jako „obcej polskiemu narodowi, obojętnie odnoszącej się do narodowych odczuć polskich robotników i chłopów"48. Wykazał tu zatem całkowity brak solidarności wobec dawnych liderów partii. Poszedł nawet dalej, oświadczając, że obecność agentów niczego nie usprawiedliwiała, bowiem masy członkowskie również podążały za szkodliwymi postulatami, m.in. w sprawie Ślaska i Pomorza. Wśród działaczy oceniajacych dorobek KPP bez większego trudu możemy wyróżnić „dogmatyków” (,sekciarzy”) niechętnych obowiązującej narracji i „pragmatyków”.

W przypadku oceny tradycji PPS dokonanie podobnego podziału jest nieco trudniejsze. Jak przypominał Daniszewski, pedagogiczny cel opracowania historii ruchu robotniczego stanowiło ideologiczne przygotowanie kadr do ich „organicznego połączenia” w przyszłości. Punktem sporu było wyznaczenie granic kompromisu w znajdowaniu wspólnego z PPS języka. Choć do opracowania obowiąującej interpretacji historii ruchu robotniczego przystępowała tylko jedna strona sporu ideologicznego, czyli spadkobiercy „nurtu międzynarodowego”, nie mogła ona jednak całkowicie zdeprecjonować nowego sojusznika, który przecież do pewnego stopnia ja uwiarygadniał.

Animozje przedwojennych komunistów wobec PPS były jednak bardzo silne. Oczywiście miały one wymiar praktyczny, gdyż stronnictwo to było przed wojna bezpośrednim i największym konkurentem KPP, zabiegającym o poparcie robotników. Obok długoletniej rywalizacji istniały również przyczyny natury emocjonalno-ideowej. Wszak przez kilka lat funkcjonowało wśród kapepowców pojęcie „socjalfaszyzm”. Było ono wynikiem przekonań kierownictwa Kominternu o zbliżającej się światowej rewolucji, do której drogę zagradzała Polska. Przeświadczona o możliwości ataku państwa polskiego na ZSRS wzywała KPP do siania dywersji w armii, przygotowywania masowego strajku oraz „demaskowania manewrów polskiego faszyzmu i socjalfaszyzmu” ${ }^{\text {. }}$. Po zwycięstwie Hitlera strategia ta została zarzucona na rzecz tworzenia antyfaszystowskiego frontu ludowego „dla obrony pokoju”, autorstwa Dymitrowa. Niewątpliwie u wielu komunistów - jak i zresztą pepesowców - spowodowało to tzw. dysonans poznawczy. Tłumaczy to silną i często obopólną awersję wielu z nich w 1946 r. Dla komunistów poszukiwanie kompromisu ideologicznego z PPS oznaczało pójście na ustępstwa „faszystom”.

${ }^{48}$ Ibidem, k. 87.

${ }^{49}$ R. Nazarewicz, op. cit., s. 37. Zob. też: K. Sacewicz, Kilka uwag na temat stosunku KPRP/KPP do PPS $w$ międzywojennej Warszawie, w: Komuniści $w$ międzywojennej Warszawie..., s. $295-332$. 
Wypowiedzi oceniające dorobek PPS są dość zróżnicowane, jeżeli chodzi o ich agresywność. Najostrzej wyrażał się Tepicht. Nie pozostawił on na PPS suchej nitki. Dekretował, iż nie jest ona żadną partią narodowo-wyzwoleńcza. Określił ją jako „partię niemiecką” (,le Parti de l’Allemagne”). Zapytywał, z jakiego tytułu ugrupowanie to reprezentowało tzw. kierunek narodowy, skoro w przeszłości zorientowane ono było na współpracę z innym imperium. Kolejne grzechy całkowicie dyskredytujące dawna PPS, jakie wymienił, to gotowość poświęcenia Wielkopolski na rzecz Litwy i Rusi, niechęć do skoordynowania działań z rewolucją rosyjską 1905 r. oraz wsparcie udzielone polityce Józefa Becka w latach trzydziestych.

Wypowiedź Józefa Kowalskiego była o wiele bardziej zniuansowana. Po stwierdzeniu, iż PPS de facto zajmowała stanowisko proniemieckie, wskazał na negatywny wpływ zarówno obcej „ideologii burżuazyjnej”, jak i II Międzynarodówki. Pozostali dyskutanci byli jeszcze bardziej koncyliacyjni. Werfel wyraźnie odróżniał PPS-Frakcję Rewolucyjną od PPS-Lewicy. Stwierdzał, że Piłsudski wprawdzie był „faszysta”, ale należało nawiąywać do „pozytywnej” działalności innych działaczy, w tym przede wszystkim Stefana Okrzei, Henryka Barona oraz Mariana Buczka. W tym samym duchu przemawiał Józef Kratko, postulując zdecydowane odróżnienie przywódców „lewicowych” z PPS-Lewicy od „prawicowych”, czyli „nacjonalistów” z PPS-Frakcji Rewolucyjnej ${ }^{50}$. Jego zdaniem współczesna PPS ewoluowała i jak mówił: „[jej działacze] przezwyciężyli swoje błędy tak jak i my" ${ }^{1}$.

Na podkreślenie zasługuje ugodowo wymijajacy ton Bermana. Jego wypowiedzi na forum Biura Politycznego KC PPR wydają się bardziej zdecydowane. Zwalczał tam koncepcje Oskara Langego postulującego oparcie partii na szerokich fundamentach ideologicznych oraz zaakceptowanie całego dziedzictwa PPS. Odrzucał radykalnie bagaż ideowy „prawicowego” skrzydła partii jako najzwyczajniej antykomunistycznego ${ }^{52}$.

Daniszewski miał świadomość, że w oczach społeczeństwa PPR może przegrać wyścig o legitymizację patriotyczna. Starając się znaleźć wyjście z tej sytuacji, przekonywał, że „Sprawa niepodległości stała się pewnego rodzaju linia podziału w ruchu robotniczym, ale oczywiście nie jedyną i nie najważniejszą" ${ }^{33}$.

50 Józef Kratko (1914-2014), oficer LWP, pułkownik MBP. Członek KPP. Służba w armii gen. Andersa (ochotnik 5 Dywizji, IX 1941 - I 1942), a następnie w armii gen. Berlinga, zastępca dowódcy Polskiego Samodzielnego Batalionu Specjalnego do spraw polityczno-wychowawczych (do V 1944), zastępca komendanta MO m.st. Warszawy do spraw polityczno-wychowawczych (VIII 1944), szef KW MO w Katowicach (1946-1947), dyrektor Departamentu IV MBP (1947-1953), dyrektor Departamentu Szkolenia MBP (1953-1954), dyrektor Departamentu VII Kds BP (1955-1956). Zob. http://katalog.bip.ipn.gov.pl/informacje/39390 (dostęp: $19 \mathrm{~V}$ 2017).

${ }^{51}$ AAN, KC PPR, sygn. XIX-5, k. 111.

${ }^{2}$ A. Sobór-Świderska, op. cit., s. 232.

${ }^{53}$ AAN, KC PPR, sygn. XIX-12, k. 2. 
Niechęć do uznania owej linii wyrażali wszyscy rozmówcy, świadomi, iż stawia ich to na przegranej pozycji. Dalszą część dyskusji zajęła próba znalezienia określeń, które umożliwiłyby przesunięcie akcentów interpretacyjnych tego, co było sednem ówczesnych podziałów. Padały różne propozycje. Zestawienie nurt „antynacjonalistyczny” i „narodowy” miał oczywiście podkreślać fakt, iż SDKPiL, a za nią i KPP nie tyle występowały przeciwko niepodległości, co przeciw nacjonalizmowi. Pozostałe propozycje dyskutantów obejmowały inne rozróżnienia, tj. kierunek „rewolucyjny” i „oportunistyczny” oraz „klasowo-rewolucyjny” i ,ugodowo-nacjonalistyczny”.

Zagadnieniem pochodnym, które dzieliło dyskutantów na „sekciarzy” i „pragmatyków”, był problem zdefiniowania aktualnej tożsamości ideowej PPR. Nie dotyczyło to bynajmniej terminologii. Podział ten był kluczowy, gdyż de facto chodziło o program partii, jej profil ideowy oraz ustrój kształtowanego przez nią państwa. Przedwojenni komuniści stanęli przy tym przed trudnym wyborem. $Z$ jednej strony przyjęcie części tradycji PPS mogłoby przyciagnąć do PPR jej dotychczasowych zwolenników, ułatwić ich integrację poprzez częściowe zakamuflowanie komunistycznego charakteru partii. $\mathrm{Z}$ drugiej strony łączyło się z ryzykiem utraty tożsamości, a w konsekwencji wyrwania im z rak steru państwa. Oprócz Werfla, który akceptował pojęcie „syntezy” zaproponowane przez Daniszewskiego, pozostali oponowali. Utrzymywali, nie bez racji, iż stawiało ono niejako znak równości między dokonaniami oraz „wypaczeniami” obu nurtów. Jak adekwatnie ujął rzecz Berman, sugerowało to słuszność pepeesowskiej koncepcji dotyczacej kluczowego zagadnienia niepodległości. Pojęcie „syntezy” zostało zatem raczej zgodnie odrzucone przez większość.

Zamykajac dyskusję nad referatem Daniszewskiego, Berman opowiadał się za tym, by mówić odtąd, iż PPR przezwyciężyła stare błędy ideologiczne i obecnie rozwija się na tle nowej rzeczywistości. Zaprezentował tu zatem stanowisko najdobitniej wyrażone przez niego na plenarnym posiedzeniu KC PPR 11 X 1947 r. Przekonywał wówczas: „Jest naszym ogromnym osiagnięciem jako komunistów, że potrafiliśmy stworzyć partię narodowa. [...] To nasz największy skarb, którego musimy bronić, i nie pozwolimy nigdy znowu zepchnąć nas do zaczarowanego kręgu KPP. [...] Nie jesteśmy partia komunistyczna, jesteśmy PPR" ${ }^{4}$.

Zachowana dokumentacja archiwalna pozwala stwierdzić, że dyskusja nad tezami Daniszewskiego miała swój ciag dalszy. W 1947 r., choć nie wiadomo dokładnie kiedy, odbyło się posiedzenie komisji konsultacyjnej WHP powołanej do oceny Zarysu historii ruchu robotniczego, czyli monografii, nad którą w tym czasie wciąż pracował. Oprócz autora w spotkaniu uczestniczyli: Berman, Dłuski, Fiedler, Leon Kasman oraz Kobryńska. Daniszewski przedstawił wówczas komisji trzy rozdziały swojej książki.

${ }^{54}$ K. Kersten, op. cit., s. 357. 
Wśród wielu zagadnień poruszanych podczas tej dyskusji kwestia stosunku komunistów do niepodległości Polski nadal znajdowała się na pierwszym planie. Widać wyraźnie zaostrzenie tonu wobec PPS. Wynikało ono zapewne z ogólnego wzmocnienia ofensywy przeciwko tej partii, jakie nastapiło po zwycięstwie wspólnej listy w styczniowych wyborach parlamentarnych ${ }^{55}$. Odosobniony Fiedler zauważył, iż będąc hegemonem, partia może sobie teraz pozwolić na kompromisy ideologiczne z PPS, uwypuklając elementy wspólne ${ }^{56}$. Pozostali wyrazili jednak odmienne zdanie. Kasman jawnie dał wyraz swojej irytacji, stwierdzając, iż w książce Daniszewski za dużo miejsca poświęcił PPS, a zbyt mało SDKPiL ${ }^{57}$. Na dodatek wymienił ja dopiero jako druga. Wszak, jego zdaniem, obie partie powstały „prawie jednocześnie”. Należało, według niego, naświetlić inne momenty i rzetelnie zrelacjonować działania obu partii w środowisku robotniczym po to, aby „znikło to niewłaściwe wrażenie" 58 . Kobryńska z kolei sprzeciwiła się takiemu stawianiu sprawy, ponieważ czytelnik mógłby uznać, iż „bliższa prawdy była PPS”, podczas gdy to kierunek „międzynarodowy” wybrał jedyną słuszną drogę ${ }^{59}$. Dodała, iż nie

${ }_{55}$ Protokół nr 2 posiedzenia Biura Politycznego z dnia 22 marca 1947 r., w: Protokoły posiedzeń Biura Politycznego KC PPR 1947-1948, oprac. A. Kochański, Warszawa 2002, s. 30-31.

${ }^{56}$ Franciszek Fiedler (1880-1956), publicysta, historyk ruchu robotniczego. Członek SDKPiL (od 1905), KPP (od 1919), WKP(b) (od 1925). Bliski współpracownik Adolfa Warskiego i Marii Koszutskiej. W 1938 r. wyjechał do Francji, gdzie w kolejnych latach współorganizował koła PPR we Francji. W 1945 r. powrócił do Polski i wstapił do PPR. Członek KC PZPR (1948-1956), redaktor „Trybuny Wolności” (1945-1947) i „Nowych Dróg” (1947-1948), wykładowca w Centralnej Szkole Partyjnej w Warszawie (1945-1948), później na UW, przewodniczący komisji Biura Politycznego KC do spraw nauki (1949-1953). W 1953 r. otrzymał tytuł profesora zwyczajnego. Członek PAN. Więcej zob. J. Jakubowski, Fiedler Franciszek, w: Stownik biograficzny..., t. II, s. 88-89; Biogramy uczonych polskich, cz. 1: Nauki społeczne, z. 1, Wrocław 1983, s. 125.

${ }^{57}$ Leon Kasman (1905-1984), redaktor. Członek KZMP (1920), WKP(b) (1922), KPP (1927). Wykładowca i zastępca kierownika sekcji polskiej w Międzynarodowej Szkole Leninowskiej w ZSRS (1934-1936), instruktor w KC KPP (1936). Podczas II wojny światowej w ZSRS. Redaktor „Trybuny Wolności” (1944-1945), dyrektor Spółdzielni Wydawniczej „Książka i Wiedza” (1946-1948), redaktor naczelny „Trybuny Ludu” (1948-1953, 1957-1967), podsekretarz stanu w Ministerstwie Przemysłu Lekkiego (1954-1956), zastępca przewodniczącego w PKPG (1956), wiceprezes NBP (od V 1968). Zob. http://katalog.bip.ipn.gov.pl/ informacje/35044 (dostęp: $19 \mathrm{~V}$ 2017).

58 AAN, KC PPR, sygn. 295/XIX-5, k. 162.

${ }^{59}$ Regina Kobryńska (1908-1978), działaczka komunistyczna. W 1914 r. wyjechała wraz z rodzina do Rosji. Od 1923 r. członek Komsomołu, od 1929 r. członek WKP(b). W 1932 r. powróciła do Polski, działaczka KPZB. Przewodnicząca KO MOPR w Białymstoku (1939), pracownik redakcji polskiej Wszechzwiązkowego Radiokomitetu w Moskwie (1941), pracownik polityczny Frontu Południowo-Zachodniego i III Frontu Ukraińskiego (1943-1944), zastępca dyrektora Centralnej Szkoły Partyjnej PPR (1944-1946), kierownik WHP przy KC PPR (IV 1946 - V 1947). Od jesieni 1948 r. do śmierci żyła w ZSRS. Więcej zob. C. Budzyńska, Kapłan-Kobryńska Regina, w: Stownik biograficzny..., t. III, s. 92; T. Rutkowski, Nauki historyczne..., s. 75-76. 
można „tak wiele darować i być pobłażliwym”60. Swoją wypowiedź skwitowała opinia, iż Piłsudski nie tylko nigdy nie był socjalista, ale i „do tego istotnej walki niepodległościowej nie prowadził"61.

Treści poruszone przez Daniszewskiego odnajdujemy do pewnego stopnia w głośnym przemówieniu Gomułki z 3 VI 1948 r. Zbieżności pomiędzy nimi aż rzucaja się w oczy. Chodzi o gotowość do uznania wkładu PPS w historii ruchu robotniczego (w tym także do pewnego stopnia jej „prawego” skrzydła), krytyczna ocenę dorobku SDKPiL i KPP oraz przeciwstawienie im PPS jako tej partii, która stale opowiadała się za idea walki o niepodległość. Elementy te znajdowały się w referacie Daniszewskiego i były szeroko dyskutowane na forum WHP. Gomułka posuną się jednak dalej. Świadczy o tym chociażby fakt, iż wbrew ustalonym zasadom nie uzgodnił wcześniej treści swojego referatu z Biurem Politycznym. Jak wspominał w pamiętnikach, w szkołach partyjnych do kanonu marksizmu-leninizmu należało nieodmiennie podporządkowanie kwestii narodowej „interesom rewolucji proletariackiej”62. W jego przemówieniu padły oskarżenia wobec KPP, podważające tę zasadę. Podkreśliwszy, iż „KPP używała hasła samostanowienia narodów w taki sposób, że sama chciała stanowić za naród i klasę robotniczą", Gomułka stwierdził, iż w polskich warunkach hasło samookreślenia „oznaczać mogło niezależnie od konkretnej sytuacji i momentu historycznego, tylko niepodległość państwową" ${ }^{63}$. Oczywiście bardzo mocno w swoim referacie podkreślał względy praktyczne. Miał na myśli to, że KPP rozminęła się z oczekiwaniami społeczeństwa w kwestii stosunku do niepodległości. Jego zdaniem powtórzenie tego błędu mogło uniemożliwić PPR uzyskanie poparcia większości obywateli. W jego ujęciu jednak nie chodziło jedynie o względy taktyczne. Dokonana przez niego analogia mogła nasuwać myśl, iż Gomułka nie dąży jedynie do rozstrzygnięcia sporu co do słuszności stanowiska komunistów wobec niepodległości Polski w przeszłości. Chodziło mu także o obronę przynajmniej częściowego zakresu suwerenności kraju, co miało szczególne znaczenie w kontekście aktualnego wówczas problemu konfliktu sowiecko-jugosłowiańskiego.

Rezolucja Biura Politycznego KC PPR z 8 VI 1948 r. odrzuciła przedstawione tezy Gomułki jako „poważne odstępstwo na rzecz nacjonalistyczno-burżuazyjnych i reformistycznych tradycji, reprezentowanych przez PPS"64. Na plenum, które odbyło się 6 i 7 lipca, wygłoszono trzy kluczowe referaty: „O dorobku ideologicznym PPR i zadaniach partii w przededniu zjednoczenia” (J. Berman), „O tradycjach zjednoczonej partii klasy robotniczej” (Marian Spychalski) oraz „O wytycznych w sprawie naszego ustroju gospodarczego

\footnotetext{
${ }^{60}$ AAN, KC PPR, sygn. 295/XIX-5, k. 164.

${ }^{61}$ Ibidem.

${ }^{62}$ W. Gomułka, op. cit., s. 383.

${ }^{63}$ K. Kersten, op. cit., s. 385.

${ }^{64}$ Cyt. za: W. Ważniewski, Walka polityczna w kierownictwie PPR i PZPR 1944-1964, Toruń 1969, s. 27.
} 
i społecznego" (H. Minc). Na ich podstawie Biuro Polityczne przyjęło rezolucję zatwierdzajacca profil ideologiczny przyszłej zjednoczonej partii. Wprawdzie nadal była mowa o „demokracji ludowej” i dezawuowano „sekciarzy” po własnej stronie, ale jednak na pierwszym planie znalazła się kwestia zaostrzenia „czujności klasowej”. Wskazywała ona na zwiększenie zakładanego tempa i poszerzenia zakresu zmian w kierunku utworzenia państwa socjalistycznego, co oznaczało konieczność przeprowadzenia czystki zgodnie z przyjętymi kryteriami ideologicznymi ${ }^{65}$.

Jak pokazały dalsze wydarzenia, w celu wyeliminowania Gomułki z kierownictwa partii wysunięto przeciwko niemu zarzuty dotyczace okresu okupacji. Zdaniem jego przeciwników „Wiesław” już wówczas miał rzekomo negatywny stosunek do Związku Sowieckiego oraz do strategicznego z nim sojuszu ${ }^{66}$. Ostatecznie Gomułkę usunięto z funkcji sekretarza generalnego na przełomie sierpnia i września 1948 r. Ostra walkę wewnętrzna, którą wywołał swoim wystapieniem, ostatecznie wygrali Bierut, Berman i Minc. Mimo że niegdysiejsze tezy Daniszewskiego, przedstawione przy prezentowaniu omawianego referatu, pokrywały się częściowo ze stanowiskiem Gomułki, nie przeszkodziły mu one w żaden sposób w karierze wewnątrz partii. Latem 1948 r. staną po stronie Bieruta, a we wrześniu tego roku zaczą kierować WHP.

Rzecz jasna, czynnik międzynarodowy - kontekst zimnej wojny oraz idąca za nim wola Stalina ściślejszego podporządkowania sobie partii komunistycznych - był kluczowy w wolcie politycznej, która nastapiła. Nie sposób jednak jednoznacznie rozstrzygnąć, na ile oskarżenia wysunięte przeciwko Gomułce zostały zainspirowane z zewnątrz. Korekta dokonana w ocenie tradycji obu kierunków ruchu robotniczego z jednej strony legitymizowała zmianę kursu, z drugiej pozwalała podporządkować sobie już bez zbędnych ceremonii pepeesowców. To zaostrzenie kursu w polityce wewnętrznej spotkało się z gorąca aprobatą wielu działaczy. Odnieśli oni wrażenie, iż PPR zdradziwszy uprzednio ideały marksistowskie, powraca na „dobra” drogę.

Dyskusja na temat właściwej interpretacji charakteru i przeobrażeń stosunku polskich komunistów do niepodległości kraju toczyła się jeszcze przez wiele lat. Wspomniana na początku artykułu książka, której opracowanie powierzono Daniszewskiemu, czyli Historia ruchu robotniczego $w$ Polsce, ukazała się w pięciu zeszytach wydawanych na przestrzeni lat 1951-1954. Obejmuja one jednak okres zaledwie do 1917 r., a zatem nie zawieraja finalnej oceny KPP. Umieszczony w nich sposób postrzegania partii „Proletariat”, SDKPiL oraz PPS nie odbiegał od tez autora obecnych w jego referacie z 1946 r. Natomiast za swoiste rozwiąanie tego kluczowego, choć niezwykle

${ }^{65}$ K. Kersten, op. cit., s. 388-398.

${ }^{66}$ Szerzej zob. R. Spałek, Komuniści przeciwko komunistom. Poszukiwanie wroga wewnętrznego $w$ kierownictwie partii komunistycznej $w$ Polsce $w$ latach 1948-1956, Poznań 2014, s. $593-672$. 
trudnego dla komunistów problemu, a zarazem swego rodzaju odpowiedź na wystapienie Gomułki, można uznać książę pt. KPP $w$ obronie niepodlegtości Polski. W tej wydanej w 1953 r. syntezie autorstwa pracowników WHP dokonano doboru dokumentów, który miał uzasadniać tytułową tezę. Właściwą wykładnię dziejów zawarto już w pierwszym paragrafie wydawnictwa, stwierdzając, że „Komunistyczna Partia Polski - okryta chwałą poprzedniczka bohaterskiej Polskiej Partii Robotniczej - czołowa siła polskich mas pracujących w ich walce o zrzucenie jarzma rodzimych kapitalistów i obszarników, o socjalizm, była zarazem niezmordowana bojowniczką o prawdziwa niepodległość i suwerenność narodu polskiego"67. Zatem ustalono, że KPP była patriotyczna, choć uzasadnienie tej tezy nie miało zbyt wiele wspólnego z faktycznym obliczem i działaniami partii. W kontekście przedstawionej dyskusji zabawne wydawać się może to, że przyjęta interpretacja odzwierciedlała w pewnej mierze tak krytykowane wcześniej stanowisko PPS wobec niepodległości Polski.

\section{Streszczenie}

Przedmiotem artykułu jest historyczna refleksja byłych kapepowców na temat ich stosunku do niepodległości Polski. Materiału doń dostarczyła analiza referatu Tadeusza Daniszewskiego, pt. „Sprawa niepodległości w ruchu robotniczym”, wygłoszonego przezeń na forum Wydziału Historii Partii jesienia 1946 r. oraz dyskusji, która wywołał. Referent oraz dyskutanci (wśród nich m.in. Jakub Berman, Roman Werfel, Jerzy Tepicht) omawiali stanowiska poszczególnych partii wobec kwestii niepodległości Polski, od narodzin ruchu robotniczego począwszy. Dokument ujawnia rozterki środowiska w obliczu konieczności zarówno legitymizacji władzy, jak i kształtowania świadomości historycznej Polaków przez najbliższe lata. Dyskutanci mieli przekonać społeczeństwo, że ci, których przed wojną powszechnie uważano za zdrajców, byli w rzeczywistości patriotami. Analiza ukazuje niebagatelne znaczenie ideologii w początkowym okresie władzy komunistycznej w Polsce, po zakończeniu II wojny światowej, oraz ciagłość dawnych walk frakcyjnych wewnątrz szeroko pojętego ruchu robotniczego na tle stosunku do niepodległości. Kluczowym elementem narracji Tadeusza Daniszewskiego, ostatecznie usankcjonowanym przez historiografię wczesnopeerelowska, jest opis ewolucji ideowej, która przeszła - wolna od wszelkich wpływów zewnętrznych - Komunistyczna Partia Polski. Dyskusja jednak znakomicie uwidacznia jedna z podstawowych osi podziału wśród byłych kapepowców, sprowadzającą się do nadążania lub nie za zmianami w obranej przez Komintern taktyce. Przywołuje ona również wygłoszony zaledwie dwa lata później, 3 VI 1948 r. na plenum KC, głośny referat Władysława Gomułki i rzuca pewne światło na ówczesny konflikt wewnątrzpartyjny. Tekst jest przyczynkiem do badań nad pamięcią byłych kapepowców o KPP i dziedzictwem przedwojennego ruchu komunistycznego.

${ }^{67}$ KPP $w$ obronie niepodlegtości Polski, red. J. Kowalski, F. Kalicka, Sz. Zachariasz, Warszawa 1953 , s. 7. 


\section{Was the Communist Party of Poland patriotic? Discussion at the Department of the History of the Party about Tadeusz Daniszewski's report on "the question of independence within the workers' movement"}

The article is devoted to a historic reflection of former members of the Communist Party of Poland about their attitude towards the independence of Poland. It is based on an analysis of Tadeusz Daniszewski's report "The question of independence in the workers' movement" delivered at the Department of the History of the arty in the autumn of 1946 and of a discussion which followed. The speaker and debaters (including Jakub Berman, Roman Werfel, and Jerzy Tepicht) presented the stances of different parties on the problem of independence of Poland, starting from the emergence of the workers' movement. The document reveals the quandaries of the communists faced with the necessity both to legitimize their power and to shape historical awareness of Poles in coming years. The main task of debaters was to convince the nation that those people who before the war had been regarded as traitors were, in actual fact, patriots. The analysis shows a considerable importance of ideology in the early period of communist rule in Poland after the end of World War Two and the continuity of old fractional struggles within the broadly understood workers' movement about the attitude towards the country's independence. The most crucial element of Tadeusz Daniszewski's report, finally sanctioned by the historiography of the early Polish People's Republic, was the description of an ideological evolution of the Communist Party of Poland, free of any outside influences. The discussion, however, made evident one of the main lines of division within the ranks of the former CPP, which amounted to the fact of keeping (or not keeping) pace with the tactic worked up by the Comintern. There is also a reference to Władysław Gomułka's well-known report delivered on 3 June 1948 at the plenum of the Party's Central Committee and sheds new light on the contemporary conflict within the Party's ranks. The text is a contribution to the studies of memory of former CPP members about the party itself and of the heritage of the pre-war communist movement.

\section{Bibliografia}

Barnaszewski B., Polityka PPR wobec zalegalizowanych partii i stronnictw, Warszawa 1996. Cichocki B., Jóźwiak K., Najważniejsze sq kadry. Centralna Szkoła Partyjna PPR/PZPR, Warszawa 2006.

Ciesielski S., Juchnowski J., Dylematy i poszukiwania. Studia nad polska myśla socjalistyczna 1939-1948, Wrocław 1991.

Cimek H., Kieszczyński L., Komunistyczna Partia Polski 1918-1938, Warszawa 1984.

Czubiński A., Komunistyczna Partia Polski (1918-1938). Zarys historii, Warszawa 1985.

Gontarczyk P., Polska Partia Robotnicza. Droga do wtadzy (1941-1944), Warszawa 2006.

Holzer J., PPS w latach 1944-1948, Warszawa 1985.

Jagiełło J., O polska droge do socjalizmu. Dyskusje w PPR i PPS $w$ latach 1944-1948, Warszawa 1983.

Kampania wyborcza i wybory do Sejmu Ustawodawczego 19 stycznia 1947, wybór i oprac. J. Wrona, Warszawa 1999.

Keller A.R., KPP i podlegte jej organizacje, czyli komunistyczne organizacje $w$ Polsce, Warszawa 1934.

Kersten K., Narodziny systemu wtadzy. Polska 1943-1948, Poznań 1990.

Kolebacz B., Komunistyczna Partia Polski 1923-1929. Problemy ideologiczne, Warszawa 1984. Komuniści w II Rzeczypospolitej. Ludzie - struktury - działalność, red. M. Bukała, M. Krzysztofiński, Rzeszów 2015. 
Komuniści w międzywojennej Warszawie, red. E. Kowalczyk, Warszawa 2014.

Kowalski J., Komunistyczna Partia Polski 1935-1938. Studium historyczne, Warszawa 1975.

Lewandowski Cz., Kierunki tak zwanej ofensywy ideologicznej w polskiej oświacie, nauce i szkołach wyższych w latach 1944-1948, Wrocław 1993.

Meglicka M., Prasa Komunistycznej Partii Robotniczej Polski w latach 1918-1923, Warszawa 1968.

Mielnicki L., Skradzione sztandary PPS, Warszawa 1987.

Nazarewicz R., Komintern a lewica polska. Wybrane problemy, Warszawa 2008.

Osękowski Cz., Referendum 30 czerwca 1946 roku w Polsce, Warszawa 2000.

Osękowski Cz., Wybory do sejmu z 19 stycznia 1947 roku w Polsce, Poznań 2000.

Polska Partia Robotnicza 1944-1948. Studia i szkice, red. M. Krzysztofiński, Rzeszów 2014.

Polska Partia Robotnicza, Gwardia Ludowa/Armia Ludowa na ziemiach polskich 19421944/1945, red. K. Kaczmarski, M. Krzysztofiński, Rzeszów 2013.

Reguła J.A., Historia Komunistycznej Partii Polski w świetle faktów i dokumentów, Warszawa 1934.

Rutkowski T., Nauki historyczne w Polsce 1944-1970. Zagadnienia polityczne i organizacyjne, Warszawa 2008.

Sacewicz, Centralna prasa Polski Podziemnej wobec komunistów polskich 1939-1945, Warszawa 2009.

Słoński B., Agentura Kominternu w Polsce, Warszawa 1937.

Sobór-Swiderska A., Jakub Berman. Biografia komunisty, Warszawa 2009.

Spałek R., Komuniści przeciwko komunistom. Poszukiwanie wroga wewnętrznego w kierownictwie partii komunistycznej w Polsce w latach 1948-1956, Poznań 2014.

Strapiński A., Wywrotowe partie polityczne, Warszawa 1933.

Tragedia Komunistycznej Partii Polski, red. nauk. J. Maciszewski, Warszawa 1989.

Trembicka K., Między apologia a negacja. Studium myśli politycznej Komunistycznej Partii Polski w latach 1918-1932, Lublin 1995.

Ważniewski W., Walka polityczna w kierownictwie PPR i PZPR 1944-1964, Toruń 1969.

Werblan A., Klasowe i narodowe aspekty myśli politycznej PPR i PZPR, Warszawa 1987.

Wrona J., System polityczny w Polsce 1944-1950. Miejsce - funkcje - relacje partii politycznych $w$ warunkach budowy i utrwalania systemu totalitarnego, Lublin 1997.

Zaremba M., Komunizm, legitymizacja, nacjonalizm. Nacjonalistyczna legitymizacja władzy komunistycznej w Polsce, Warszawa 2005.

Bi o g r a m: Katarzyna Losson - doktor historii, absolwentka Katedry Ukrainistyki Wydziału Lingwistyki Stosowanej i Filologii Wschodniosłowiańskich oraz Filologii Nowogreckiej Wydziału Artes Liberales UW, Wydziału Historii Université Paris X Nanterre oraz Wydziału Historii Międzynarodowej London School of Economics. Specjalizuje się w zagadnieniach związanych z historią idei. Autorka monografii pt. Komu miła całość Ojczyzny. Świadomość $i$ aspiracje polityczne kancelistów kozackich (1670-1720), Warszawa 2013. E-mail: katarzyna.losson@gmail.com. 